\title{
Theatres of Closure: \\ Process and Performance in Inhumation Burial Rites in Early Medieval Britain
}

\author{
By Sue Harrington, Stuart Brookes, Sarah Semple and Andrew Millard
}

\begin{abstract}
Inhumation burials are recorded in Britain and Europe during excavations in a standardised way, especially graves of early medieval date. Just a limited number of attributes are usually foregrounded and these mainly concern skeletal identification, the grave plan, and, when a burial is furnished, a list of objects, particularly metalwork as well as occasional reference to burial structures if present. In this paper we argue that concealed within these recorded details are attributes that often receive little attention, but which can provide evidence for community investment in the individual funerary rite. These include grave orientation, grave morphology, the body position and the empty spaces in the grave as well as categories of material culture. We argue here that these factors enable us to define communal burial profiles and can facilitate the identification of group perceptions and actions in dealing with death. By capitalising on these additional aspects of funerary ritual, archaeologists can move away from a general dependency on well-furnished burials as the main stepping off point for discussion of social and cultural issues. This has particular relevance for regions where unfurnished burial rites are the norm and where furnished rites do not rely on a wealth of metalwork.
\end{abstract}

\section{INTRODUCTION}

The death of an individual involves a transition from the world of the living to the world of the dead and the disposal of the body is often just one part of an elaborate sequence of funerary rites performed by the mourners (van Gennep 1960, 146-7). In many societies this involves the washing and dressing of the body and a close proximity for a time between the mourners and the deceased. Sooner or later, however, the remains will be transformed and disposed of in some way, perhaps by inhumation, exposure, entombment or the scattering of cremains. These mortuary processes are mechanisms by which memories and identities are constructed, and this is as true for the past as well as the present (Williams 2011,93 ). While a wide range of variability exists in the outward appearance of burials, all mortuary practices, now and in the past, involve-we arguebasic and unavoidable elements, an elective algorithm that encompasses the acts of selecting a location, digging a grave and, in the case of inhumation, the positioning of a body, and on occasion the addition of a marker. These small acts mark stages in the transition of an individual from life to death. Here we term this dramatic process the 'Theatre of Closure': a sequence of choices operating within a socially- and culturally-mediated conceptual framework in which inhumation burial is a prime disposal method.

The full complexities and nuances of the different aspects of inhumation behaviour and its uses in early medieval Britain, selected as a case-study here, are beyond the scope of this paper, but we take our inspiration from several broad consensuses in recent contemporary analyses. Firstly, there is a recognition that mortuary assemblages are more than mere passive reflections of past social systems, and that the expression of identity in burial represents what might be regarded as political and symbolic acts through which wealth, cultural position, gender, ideology and affiliation can be manipulated (e.g. Samson 1987; Härke 1990; Halsall 2003; Williams 2006, 36-78). Secondly, that the act of burial itself was a performative rite - a narrative, yet physical production (Williams 2006, 1-35) - in which the deliberate placement and selection of goods by the living could be used to mask and exaggerate these same inequalities (e.g. Pader 1982; Williams 2006, 27-31). This staging of ritual involved living and material agents, the performance guiding group memories and stimulating 
collective mythologies (Williams 2001; 2006, 20-7). Such processes have been described as a form of text, poetry or theatre that served to embed memories and stories within the minds of the living (Carver 2000, 36-7; Williams 2006, 118-21; Price 2010).

Aspects of this 'theatre of closure' present themselves, wholly or partially, in the archaeological record, but there are significant challenges in elucidating the interplay between the practicalities of burial and the conceptual framework that dictated discrete actions. Our approach, while recognising archaeological evidence is itself an 'interpretative construct' (Chapman and Wylie, 19), embraces the opportunity to extract some of the most basic and often overlooked elements of early medieval burial rites and compare them and explore and reform that evidence to greater degrees of nuance. A grave is not an essential requirement for body disposal and thus we cannot separate the processes of closure involved in inhuming, covering and marking the body from deposits they contain (Williams 2006, 117). Archaeothanatology, as espoused by Henri Duday (2009), while primarily focussed on the spatial relations of the bioarchaeological remains with the grave-space and objects, encourages the use of detailed recording of all elements of burial in situ and their spatial relationships, to extract new information on the holistic context of the burial act. While the skeletal remains and bioarchaeological evidence are not our primary concern here, we take inspiration from this approach, using the detail of the grave-space to explore elements of choice and human investment at the graveside and the ways in which the framing and concealment of the cadaver may have been part of an extended ritual performance. Our exploration is intended to advance on the research cited above on the performative nature of early medieval burial practices (e.g. Carver 2000, 25-48; Williams 2001; Halsall 2003, 66-7; Williams 2006, 117-44; Price 2010). Inspired, as well, by the substantial number of minimally furnished and unfurnished inhumation graves that characterise the northern English dataset, our intention, here is to explore the norms of mortuary ritual in terms of grave construction, body placement and grave closure, alongside the evidence for furnishing them with meaningful materials. By refocusing attention on the non-artefactual attributes of disposal and on what can seem the more mundane elements of mortuary performance, expression and investment-the location, digging, filling and marking of the grave-we may highlight 'bottom-up' processes that could be of value in characterising community approaches and variability in the rites of passage that accompanied the journey of the deceased.

Drawing on two substantive and recently generated British datasets, ${ }^{1}$ in this article we explore and compare the performative nature of inhumation burial rites in the emerging political entity of Northumbria within the late fifth and sixth centuries $A D$ and in the early medieval kingdoms in southern England. We question if these communities shared the same kinds of ideas and processes in terms of the inhumation burial rite and if similarities and differences in community structures were expressed within the burial scene in the technologies used to successfully transform the body of a living member of the community to a venerated ancestor. While cremating communities were present in both regions, and some sites discussed were bi-ritual for a time, our focus here is the inhumation rite, shared by the vast majority of burying communities in mainland Britain in the fifth and sixth centuries AD. Likewise while many of the inhumation burials drawn upon

\footnotetext{
${ }^{1}$ This article makes use of data generated from two Leverhulme Trust funded research projects. People and Place: the making of the kingdom of Northumbria $A D$ 300-800 is the latest in a series of projects that have had, as an underpinning research tool, a comprehensive database of sites, burials and artefacts of the late Roman/late prehistory to early medieval period in order to investigate fundamental issues about polity and state formation in this era. The second dataset, from the Beyond the Tribal Hidage project, covers all AngloSaxon cemetery sites south of the River Thames and as far west as Somerset, recorded in the same format. This area comprised the emerging kindgoms of Kent, Sussex and Wessex and provides a template, due to its wealth of excavated sites, for interpretations of community structures and social change.
} 
in this study contained surviving skeletal remains, our focus on the grave construction, the cemetery and setting. ${ }^{2}$

\section{GRAVE THEATRE AND THE ACT OF CLOSURE}

The standardised way in which inhumation burials are now published, especially those of early medieval date in Britain and Europe, captures and foregrounds a number of the excavated attributes. The bulk of discussion is usually delivered around the assemblage, in terms of artefacts present, primarily metalwork, with the aims of characterising chronology and assessing the material wealth of the buried community. An important methodological aspect of early medieval funerary archaeology is that graves of the fourth to seventh centuries are usually drawn, both the grave shape, the position and extent of the skeletal remains, and the location of any objects, containers or animal remains found within the cut (Fig. 1a). In later cemeteries in England, of the seventh/eighth century and beyond, such detailed records are often absent, perhaps due to a belief that without the elaborate assemblages, fittings and staging of pre-Christian and conversion-period rites, there may be little gained in detailing the grave plan (Fig. 1b). Even so, the reports and publications of cemeteries of the fifth-seventh/eighth centuries with detailed grave plans will capture information attributes which are then overlooked within the analysis and interpretation.

We might count grave size and shape in this category of under-explored information as well as details on body placement and posing, evidence for 'voids or 'empty spaces' within the grave and indications that organic materials were included (Williams 2006, 117-23). We argue here that these factors can be interrogated to offer new insights into how past societies dealt with death and new stepping off points for discussion of social and cultural issues, particularly in regions with relatively little metalwork visible in the burial record. The burial and its grave plan are a static survival, yet the creation of a burial assemblage was a series of processes for which we often only discuss the outcome as presented in the grave plan. The choosing, digging and building of a grave had intentionality and as we will see, the results are not uniform within or across cemeteries of early medieval date. These processes were components in the mortuary performance and elements in the technologies of remembrance employed at burial, yet the data itself is underused.

Firstly, we need to consider the sequence of decisions and choices made after the death of the individual - the elements that together form the extended ritual performance of framing and concealing the cadaver - along with the possible impulses and the potential for archaeological survival. What follows here is an overview of archaeologically recovered data sorted into phases of activity necessary to disposing of a body using an inhumation rite. Although our observations relate mainly to what Leclerc (1990) has termed 'primary burials', that is a single ceremony during which human remains are interred as opposed to multiple phases of decomposition and interment, some of the same issues are relevant also to the latter.

1. ARCHITECTURE AND STAGING — LOCATING AND CREATING THE GRAVE

Many have made compelling arguments for the selection, design, and adaptation of spaces in order to carry out the mortuary ritual (e.g. Williams 2006, 145-58; 2014; Semple and Williams 2015). Amongst the concerns thought likely to influence the location and placement of graves are visual details symbolising personal and kin relationships and identities, along with practical issues such as the availability of space for interment and the performance of burial rituals. Some aspects of these concerns are potentially archaeologically recoverable. The shape of the grave, its depth, and

\footnotetext{
${ }^{2}$ Closer integrated analyses of northern early medieval mortuary processes, bringing in bioarchaeological data, are forthcoming from the Leverhulme-funded project People and Place: The Making of the Kingdom of Northumbria.
} 
the verticality of the cut are also meaningful acts. While the soil composition, geology, ground moisture and even weather are all agent in shaping the grave-digging process, the act of digging is still laden with meaning (Williams 2006, 117). While we cannot make simple equations between expended labour and the identity, status or societal value of the individual and the associated mourners, nor indeed the size of grave with respect to body, we can measure and compare these acts of grave-digging within the broader funerary repertoire as significant elements of framing, performance and closure that reflect fundamental individual and group concerns about death that potentially transcend worldly concerns. Similarly, the orientation of the grave-whether oriented to cardinal axes, other graves, or significant landscape features-is a result of an intentional process. Authors in the past have noted the ways in which cemeteries seem to have single and multiple foci (Evison 1987; Sayer and Wienhold 2013: 73-4), and while relationships between grave orientation and the sunrise (see Hawkes 1976) have been dismissed, the effect of pre-existing and contemporary monuments on grave placement and developing cemetery layouts is now well acknowledged (Williams 2006, 150-67). The clustering of graves in cemeteries has also been explored as a reflection of social organisation and households, further underscoring the intentionality in grave emplacement as a careful and symbolic choice and part of the closure narrative (Sayer and Wienhold 2013).

\section{THE BODY}

The staging of the body in death can similarly be read as the result of intentional placement and the process of interment (Williams 2006, 79, 102-8). The extent to which this staging is reflective of the individual can be debated: the handling, placing and positioning of the dead cadaver by the living is more likely to be moulded by family and community expressions of appropriate concepts about life and death, liminality and ending. It is such concepts that are perhaps the most difficult element to extract from the archaeological evidence, as body positions can be altered through decomposition and taphonomic processes (Knüsel and Outram 2009; Duday 2009). Nevertheless, patterns and variations in the positions of dead bodies in the grave could be used to express aspects of the deceased's social identity and their relationships with other people (Williams 2006, 102-8, 114-6; Mui 2015; 2018). Important characteristics include the postures, gestures and other arrangement of the body, head positions and the direction of the deceased's 'gaze', and location of the body in the grave - many aspects of which are archaeologically recoverable. Another significant dimension in staging the body may also have been its concealment, through the use of clothing as body wrappings, actual shrouds, and layers of cloth, plant matter, coffins and other coverings, or the placement of objects (Williams 2006, 129-31; Mui 2015). In the absence of surviving physical objects, such aspects are sometimes difficult to infer, however can sometimes be hinted at by the movement of bones through decomposition (e.g. Duday 2009) or the unusual position of the body (e.g. Burial 27, Sutton Hoo, Suffolk; Carver 2005, 322, 327-29). Similarly, taphonomic processes may also impinge on our ability to reconstruct the character of body in relation to organic furnishings and objects included in the grave. Textiles, organic materials, and food stuffs, for example, may leave little or no trace in the grave assemblage, but may have played a significant part in the burial ritual. In these instances, the empty spaces in the grave and their position relative to that of the body may provide important negative evidence for the ways in which the body was presented and accompanied. Multiple burials often demonstrate striking and complex staging, for example when two or more individuals were placed in the same grave (Mui 2018) or humans and animals (Mortimer et al. 2017). 


\section{PROPS/OR FURNISHINGS}

Unique and group expressions were also possible in the burial arena by use of objects and furnishings and elements of costume. Complex ritual sequences can be extracted from the archaeological evidence, for example at Snape in Suffolk, where it is possible to tease out the stages of preparation, from the storage of the cadaver to the preparation of the grave, the choice of container, the addition of objects, the use of textile wrappings and perhaps leaves and bracken as coverings, and finally a structured backfilling process which involved the deposition of additional objects (for a detailed breakdown see Williams 2006, 124-35 drawing on Filmer Sankey and Pestell 2001). Snape, of course, had unusually well preserved evidence and many of the burials, perhaps as a result, appear richly kitted out. In the northern burial repertoire, the evidence for the fifth and sixth centuries is significantly sparser, with organics, skeletal remains and even metalwork devoured by the acidic soils (Maldonado 2013, 12). Here, however, the grave-linings, stones, and coverings used consolidate the grave cut, to structure the position and arrangement of the body in the grave, can still constitute and inform on meaningful ritual action (e.g. Williams 2006, 141-4; see Maldonado $2011,110-12 ; 2013,12-17)$. The purposeful selection of stone for linings and the reuse of carved fragments demonstrate active choices in grave preparation (Maldonado 2013,15). Traces of biers or coffins survive from north and south and while they served a functional purpose, aiding the lowering of the body into the grave, hint at movements and rituals associated with the performance of the burial rite (Ibid, 16). The range of non-costume objects often found within graves, including tools, weapons, and personal effects were added to and arranged around the burial potentially in a performative process (Carver 1998; 2005; Williams 2001; 2006, 137-41. Many additional objects may of course have been organic and therefore with marginal survival into the archaeological record, for example textiles, furs, plant remains etc (Harrington 2007). Depending on the depth and size of the grave cut such objects may alternatively have been dropped or carefully lowered from outside the grave, or arranged by individuals within it. However enacted, details regarding the position, orientation and form of grave goods potentially carries additional information regarding the spectacle and performance of the burial ritual.

\section{CLOSURE, MARKERS AND MEMORY - ENDINGS}

The closure of the grave would have been equally ritually charged. From the covering over of a body with textiles or plant material, to the conscious structured filling of a grave with different of soil, perhaps with contrasting colours, the evidence of early medieval inhumation graves suggests that structure processes of closure were integral to mortuary activities (Williams 2006, 129-33). Although not the focus in this article, other physical objects could be added at this juncture or later with the purpose of marking the grave, including earthen mounds, mortuary houses, timber or stone markers (Ibid, 147-58). The creation and construction of monuments was an element in the act of closure, yet these were also agent in the continuing choreography of visual and physical engagement with a place of burial by the living, offering the potential to model the experiential nature of the grave and cemetery if archaeological evidence allows.

Mortuary rituals can carry on beyond interment of the body. Graves may be subsequently re-visited or even reopened, perhaps in order to commemorate the dead, to remove or reorder grave goods and other remains, to insert more bodies or violate the physical remains (Blair 2009) or rob the grave of precious objects (Klevnäs 2013). In other cases, burial sites might be deliberately avoided. Cemeteries had a finite life, with burial grounds moving to another location in the vicinity or being shunned in the light of new concepts around appropriate burial, most obviously in the early medieval period to bounded churchyards within a Christian tradition. 


\section{OLD DATA/NEW METHODS?}

Our starting point for investigating ways of unpacking theses less dramatic but no less important elements of the structured ritual action of the funeral is the assertion that traditional excavation reports do inadvertently capture more details of the burial process than have been explored to date. From the above discussion, it is obvious that there is the potential for a great deal of variability and possible choices within the burial performance, presenting archaeologists with the challenge of capturing this data and inferred processes as a means of generating insight into past communities. The adoption since the 1960 s of a more uniform format for recording excavated inhumation graves, inspired by continental scholarship, and exemplified by, for example, the reports of the Kentish cemeteries at Buckland Dover and Finglesham (Evison 1987; Hawkes and Grainger 2006), offers a rich starting point from which to explore the evidence for these potentially overlooked processes of grave construction and closure. Significant advances have also been made at key sites, such as Sutton Hoo, Suffolk (Carver 2005), and West Heslerton, Yorkshire (Haughton and Powlesland 1999), where new methods of investigation, recording and visualising inhumation graves were developed. At the heart of all such reports is the grave catalogue, grave plan, a discussion of artefact types and a general overview of the site layout and phasing and usually a grave-by-grave record of skeletal remains and objects recorded as excavated. ${ }^{3}$

An increasing number of research projects, whether PhD-based or larger scale projects, harness these kinds of data, capturing digital information on individuals, graves, cemeteries and monuments for the purposes of broad-scale study of funerary trends and early medieval/medieval activity more broadly. Large-scale compilations of burials, recently completed or currently underway, include Mapping Death, a study of burials in Ireland from the first to the eighth centuries AD (Bhreathnach et al. 2010); Requiem, recording some 8000 graves from 70 cemeteries from principally medieval religious houses (Gilchrist and Sloane 2005); and Cimiteri Altomedievali in Italia Settentrionale (CAMIS), recording the published data of more than 1000 late antique and early medieval cemeteries across northern Italy (Chavarría Arnau and Brogiolo 2013; Chavarría Arnau 2019).

The authors of this paper have likewise developed, and cumulatively integrated, the AngloSaxon Kent Electronic Database, the Beyond the Tribal Hidage Project, and the People and Place: the Making of the Kingdom of Northumbria dataset (Brookes et al. 2006; Brookes and Harrington 2008; 2013; Harrington and Brookes 2019; Harrington and Welch 2014; Semple et al 2017), providing extensive coverage of early medieval England and southern Scotland. Like the excavation reports they draw on, these datasets collect attribute information about the burial site as a monument, recording to a common data standard spatial and temporal information, the number and form of burials, a precís of the excavation history of the site, and bibliographical sources. Together the entire dataset can facilitate rapid surveys of core attributes, distilled from published and unpublished reports, and allow for a standardisation of nomenclature of burial features and artefacts. The digital format makes it easy to search for individual components across the corpus (e.g. burial form, artefact types), and in the cases where images are also provided, allows for the virtual reunification of the assemblage. Digital data are also interoperable with other software, enabling for example, statistical or spatial analyses (e.g. spatial distributions; parametric and non-parametric testing). These technological advances are not without their inherent problems. The question must be asked

\footnotetext{
${ }^{3}$ Since the early twentieth century, basic osteological and biometric data has been incorporated but only in recent decades has its inclusion become normative and standardised (Roberts and Cox 2003). Now excavation reports will also contain an osteological report but also additional scientific data on the skeleton, including (subject to funding) DNA, strontium isotopes and radiocarbon dating (e.g. Roberts 2014).
} 
as to whether such bespoke digital structures can contain the total sum of information we can gather about past communities and whether the formats might reflect the biases of those building databases and acquiring data. Yet such attempts at detailed and standardised large-scale recording may for insights into hitherto unrecognised aspects of behaviour.

In this paper we discuss just five components as a way of enhancing approaches to studying burials and tapping the unexplored potential of existing datasets. While People and Place: the Making of the kingdom of Northumbria AD 300-800 deals with regions beyond Anglo-Saxon political control and a deeper transitional time-depth, for this study we opted for sites from all parts of early medieval England where inhumation was dominant and restricted our time frame to the fifth and sixth centuries AD. This allowed us to explore whether the particular attributes were uniform across the communities living in the south and north and if a consistent cultural context could be established perhaps linked to specific conceptions of regional identity; or conversely, if diverse and locally driven ideas of disposal were in operation in tandem with broad changes towards furnished inhumation practices involving the use of continental-style artefacts and dress fittings. The following sites were chosen for comparative study on the basis of their well-organised published or unpublished material and with good quality drawn grave plans. Only those inhumation burials certainly and probably within the time frame of the fifth and sixth centuries were used (number in brackets), although several cemeteries continued in use over a longer period. Where graves are identified by a wide date range, they are included if the major part of that date range falls within the period to AD 600 (Table 1, Figure 2).

The data from 822 individuals was already in a unified format, but this was extended by the addition of qualitative categorisations (Tab 2). All grave plans were digitised to allow cross comparison of size, shape and volume, together with the outline of the body. The grounding premise of this investigation is that community investment in burial appears in all stages of the burial rite. We opted to concentrate on the most basic elements as being the best recorded attributes and these were investigated sequentially (Tab 2).

Commencing with the most clear-cut elements, those of orientation, grave shape and body position, we began to question what nuances in funerary action may have been overlooked in our interpretations of furnished burial rites by accessing the less-well researched elements of mortuary theatre: the effort that preceded the funerary but had a prominent purpose in staging the funeral. This in turn allowed us to comparatively interrogate the intentionality underpinning the construction of the inhumation tableaux. By using cross comparable data from contemporary but spatially separate sites, we were able to explore evidence for the wider societal impulses as reflected in discrete communities and potential variations in how communities approached inhumation disposal rites.

\section{GRAVE ORIENTATION}

This is an element of grave architecture, formed by a choice of how to align the grave cut spatially in the first stage of decision making. The capacity of the digital datasets means that county or regional overviews of grave orientations are possible, but also trans-regional assessment as well. This, for example, can enable us to challenge assumptions about the reversion to east/west burial resulting from Christianising and continental Frankish influences on southern and eastern (Hawkes 1982) and perhaps test out latent late Roman preferences for W-E inhumation rites in northern communities (Petts 2002). The dataset presented here is rectified and verified for the sample sites. The orientation of the grave cut (and the body within) is reconciled to eight options and in each case the head position is given first. These are: E-W; W-E; N-S; S-N; SW-NE; SE-NW; NE-SW; NW-SE.

Radar plots of the relative frequency of orientations (as percentage of buried population) show two main trends (Figure 3). The three sites of southern England-Butler's Field, Grove Farm, 
and Mill Hill-demonstrate a more consistent SW-NE burial orientation than northern cemeteries, where a greater variety of orientations is evident. In the northern cemeteries, no single orientation dominates, though W-E and NW-SE are consistently well represented across all these sites, particularly the two inland ones-West Heslerton and Scorton-where these orientations account for respectively $60 \%$ and $83 \%$ of all graves. It is noticeable that by contrast in the two coastal sitesCastledyke South and Sewerby-there is a more uniform distribution across all orientations with between $4-26 \%$ of the population buried in any one direction. Taken by itself, the wide variability exhibited by these communities, suggests the absence of any dominant burial norm. Indeed, even in the southern group, where a notion of such standardization might be hypothesised, between 22$36 \%$ of burials deviate from the general SW-NE trend, suggesting that variations beyond the limited norm could be deployed, if not to a great extent.

Mill Hill, Deal, the site in this study lying closest to Frankish-Christian influence, has the most consistent burial orientation of any community, however it is SW-NE that dominates, rather than WE. The graves at Market Lavington and Butler's Field too show a striking preference for SW-NE orientations. Intriguingly, the sites that display the greatest numbers of burials orientated W-E are the examples that lie further north and inland: West Heslerton and Castledyke. In general, each community seems to have made its own choices, with no cemetery profile exactly like another. The development of the site plans was not necessarily linear or progressive, as many began as multifocal and development remained organic over time. However, as this visualisation demonstrates, with the caveat that this is a small sample, there appears to be a major difference between the north and south in the freedom to choose a grave orientation, something which would benefit from more extensive exploration.

\section{GRAVE MORPHOLOGY}

This area of investigation concerned the planning and digging of a grave, following on directly from the choice of grave orientation. Whilst digging equipment does not appear as a grave good in early Anglo-Saxon burials, there are examples of agricultural tools from the Roman period (Manning 1985) that demonstrate the range of capabilities available. Manning presents (ibid., 44) iron spade sheaths with round and straight profiles-introduced to Britain by the Romans-and mattocks of a form familiar to modern excavators. The latter come in a large military form and a smaller civilian one. With these two tool types alone a grave of any size might be cut, regardless of soil type (stones could be levered out using stout poles). Bone picks were probably still in use. Banham and Faith $(2014,41-2)$ suggest that digging was an essential element of arable farming wherein 'hand-tool agriculture, whether with spades, hoes or digging sticks was probably as widespread as ploughing' (ibid. 41). Constraints might of course be the soil type and underlying geology, the time available to complete the excavation, and the uses to which it would be put. As regards making a coherent size and shape, this could be achieved easily through the use of a stick notched with the required width and length for laying out and the 'rule of eye' to create parallel sides. If this was the case, then any variations in the grave shape (rounded or bulbous ends) would actually have been more difficult to produce and might hint at needs beyond those of simple bodily deposition.

Information on grave shape was drawn from the published record and of course while drawing conventions may have smoothed out irregularities or excavation issues, what was published has had to be accepted here as accurate. Grave shapes derived from the cemeteries in question did not resolve easily into a set of uniform categories. Initial descriptors assessed the overall shape in terms of rectangular, round, square or irregular, further partitioned into whether or not the rectangular shapes were uniform or semi-rounded at one end. Truncated graves were omitted. While the variability of the drawn record resulted in a certain amount of subjectivity, certain 
features did stand out. For example, there were no sharp corners as all returns were rounded to some degree. There were few exactly straight lines, although one end might be straight and the opposite end more rounded. Some shapes were more sinuous than others. Eventually only three grave shape descriptors were used (Tab 3), as the basic shape of any grave was variant on a rectangle due to the human body shape.

Comparison of the data indicates that there is a general lack of conformity in grave shape across all of the cemeteries in the sample. In most cases only around a half of graves adhere to one shape or other; Mill Hill, Deal is the only site exhibiting greater regularity both in the proportion of the community and the shape of grave cuts. Besides Mill Hill, Deal some sites might be regarded as displaying a general tendency towards more regular cuts, such as Sewerby, Scorton and West Heslerton, where irregular cuts are rare. This contrasts with Castledyke South where very few grave cuts were of a regular shape and most were irregular. But overall, no clear picture emerges.

If the skills and time were available to lay out a regularly-shaped burial, as in $47 \%$ of all those recorded, what might be inferred regarding a lesser degree of regularity in grave plan? It is possible that non-regularity indicates haste, a lack of available labour, the low status of the interred, or the low status of the burying group responsible. Alternatively, could this indicate that the intended contents of the grave did not conform to a regular shape, or could not be moulded into one? The latter proposition may suggest that the tableau of burial and accompanying grave goods were of greater importance than locating and digging the grave, yet if this is the case, paradoxically individuals at Mill Hill, Deal contained on average more objects (5.67) than others in the sample (Butler's Field Lechlade has next most with an average of 4.02 objects per individual) pointing here to a linkage between investment in terms of effort and regularity and in goods deposited, symptomatic perhaps of more controlled and managed practices or indeed group expectations regarding disposal theatre.

\section{BODY POSITION}

An intermediate act of lining a grave with organic material, such as wood, cloth or plant fibre or indeed furniture of some kind, is well-enough attested to not demand further consideration at this point. Due to the relatively poor survival of organics, it cannot be assessed as to whether this was a universal trait. Coffins are present in the study sample (61 examples) and these occur in the same proportions of grave shapes as uncoffined burials. The next major action considered here, therefore, is the deposition of the human remains. A range of body positions have been determined from the reports grave plans, rather than the text, as there are terminological differences. For example, what is given as 'crouched' may actually be visually more similar to 'flexed'. The terms identified here (Tab 4) are far coarser grained than recently completed and detailed work on body and arm positions (Mui 2018), but are sufficient for the scope of this investigation.

Taken as a whole supine is shown to be the most frequently used body position (50\%) (Fig $5)$, however, the proportions of bodies interred in this way vary within cemeteries. Again, the Mill Hill, Deal community exhibits greater regularity with nearly all (95\%) of individuals supine.

Elsewhere, other body positions are better represented particularly flexed bodies, which make up nearly a quarter (23\%) of the total corpus, and are as or more common a position as supine at Sewerby, West Heslerton and Castledyke South. Prone and crouched bodies are much more a feature of northern cemeteries and although marginally present in the southern ones, they are completely absent from Mill Hill, Deal. Crouched burial rites are recognised as an attribute in inhumation rites in Yorkshire, but have been argued to be a potential seventh-century innovation (Lucy 2000); however, in the northern cemeteries considered here, crouched is just one of several varying body positions adopted by the burying communities. Similarly, a broader study, focused especially on conversion period rites has identified a high proportion of prone burials in northern 
cemeteries generally (Craig 2010), something corroborated here in the high proportion of prone burials in the study sites.

This contrast between north and south is less visible in the proportions of extended body positions: Butler's Field Lechlade and Market Lavington have similar numbers of such individuals as Castledyke South and Scorton. At Sewerby they are entirely absent. What is evident is that again there were greater opportunities for variations in practice in terms of body placement in northern communities, something now born out in an extensive and wide-ranging study of Anglo-Saxon mortuary theatre by Sian Mui (2018).

Previous analyses of early Anglo-Saxon burials have attempted to correlate body positions with particular social personae: Martin Foreman (1998, 333-4), for example, in his discussion of Castledyke South proposed variable positions by age. Sue Hirst $(1985,27-8)$ discussing the Sewerby inhumations suggested that crouched burials may result from the legs being tied together, causing them both to fall in the same direction, likewise the prone 'live' burial in grave 41 at Sewerby was interpreted as a sign of treatment specific to perceived social deviance. Ethnic attributions have also been asserted in the past and countered: crouched bodies were once argued as long-standing 'native' burial traditions evident in prehistory with their reappearance in the early medieval era in the north-east (see for example Faull 1981). Yet these still occur in the seventh century and in Yorkshire a reassessment of their date implies they may be a sixth/seventh-century innovation rather than an enduring indigenous tradition (Lucy 2000). Outside Kent, the variety of body positions make assumptions about the identity of individuals difficult to generalise about. The apparent absence of normative treatment would suggest an acceptance of difference that was allowed and featured within the mortuary performance rather than pressure to conform to shared norms.

\section{SPACE AROUND THE BODY}

Observations made above regarding the (ir)regularity of graves and the positions of bodies leads one to query whether there might have been organic material artefacts under and around the legs that supported them initially as part of the burial tableau. Some indication of such objects may be suggested by the amount of space or 'voids' contained in graves. The process of data collation for the two research projects has made it apparent that the grave space was in some cases larger than that required for the body and the surviving objects, moreover the position of the surviving skeleton sometimes appears to suggests that 'additional space' was somehow required (e.g. Butler's Field Lechlade grave 90 depicted in Figure 6). Grave size and the size of voids might be taken together to reflect another element in the care/investment taken in excavating the grave that we can connect to the intentions of the living-perhaps a large number of voids represents more missing organic material and thus more investment and value in the identity of the deceased, or different kinds of disposal processes linked to particular groups, regions or even cosmological drivers of the family or community?

In ideal circumstances such voids would be calculated volumetrically, however the depth of the original grave cut would not be reconstructable as variations in the amount of truncation make it impossible to gauge original ground levels in all but the most exceptional circumstances. How do you factor for ploughing, flooding and/or other subsequent events that may have eroded the grave site and thus affected its depth?

Neither is it possible to know whether the body was lying wholly flat on the grave floor, whether organic material or artefacts underlay it or whether it was propped up to look out at the burying community before closure. Analysis of the relative 'volume' of graves therefore restricts itself only to the two-dimensional grave plan (Figure 6). Digitisation of the burial plan and outline of the body allow for a crude quantification of the amount of empty space in graves. 
While average grave size varies across the sample from $109 \mathrm{~cm}^{2}$ (Sewerby) to $150 \mathrm{~cm}^{2}$ (Market Lavington), the average proportion of 'additional space' at most sites is relatively similar at 69-77\% (Figure 7). Two sites stand out through this analysis. While the grave sizes at Mill Hill, Deal fall within the range of other sites, there is significantly less empty space. Also noteworthy is Castledyke South, which has the second smallest average grave size, but by far the largest 'voids' (87\%).

Closer inspection of the data provides some explanation for these discrepancies. Banding graves by age corrects to some extent the range in grave areas. Of the cemeteries in the sample Market Lavington has the smallest proportion of infant, immature and juvenile graves (11.11\%); Sewerby (along with Butler's Field Lechlade) the greatest (both 25\%). On average the graves of these younger individuals also contain greater amounts of empty space, an attribute not necessarily explainable by the smaller body mass combined with the digging of a standard sized grave. Here, the grave area may relate to now absent organic material. Thus, Castledyke South is revealed to be in agreement with the pattern of burial recognised elsewhere. On the whole this analysis shows the relative consistency in the percentage of voids in graves outside of Kent - the somewhat erratic form of the Sewerby curve notwithstanding. The strong relationship in the date, both in terms of the shape of the curve by age banding, and the average percentage of empty space by age, suggests some generalizable patterns in burial practices; though again the community of Mill Hill, Deal is somewhat aberrant in its behaviour which might again concur with this community adhering to a more proscribed format for burial rites than others.

\section{GRAVE GOODS}

Whilst individual bodies were clearly prepared for deposition using, in many cases, dress fitments to secure cloth and clothing, a range of other goods were also deposited adjacent to or around the body. What did all of this material represent? Any modern attempt to categorise the meaning of these grave goods involves making an interpretative judgement and there will always be blurred distinctions - for example a dress fastening, brooch or buckle may easily have operated as a personal effect, an heirloom, an amulet and a dress item. For the purpose of this paper the aim was to categorise the surviving artefactual material without introducing a pre-ordered hierarchy of form and perceived value, presented as the key elements of wealth. To ably compare acts of deposition and furnishing between north and south in terms of investment demanded a different scheme of quantification. Here, experimentally, the form of objects has been related to their function brooches as pins, pots as containers and so forth - allowing the objects to be categorised into six groups (Tab 5). It is acknowledged that the intentionality of deposition in the grave makes it difficult to separate out some categories, for example, dress fitments from personal effects, likewise 'containers' encompasses objects deposited in their own right and vessels containing perishable goods, but such distinctions have been used previously in a variety of published cemetery analyses and here this artificial categorisation merely form a starting point from which to comparatively explore investment in individual inhumation graves.

Each individual was given a score from 0-6 based on the number of categories, of whichever kind, present within their assemblage, disregarding the actual number of items. Clearly, a weapon burial might be expected to fall into the top category with all 6 attributes (sword-shaped weaving beaters were categorised as tools), but most weapon burials did not achieve this score. It was also decided not to prejudge potential gender associations of certain objects by splitting the data between male and female burials. 
Superficially, the produced plots fall into two main profiles (A) and (B) - one in which there is a more-or-less steady decline from a majority of individuals without any category of grave-good to those with five or six. The other profile resembles a normal distribution with the majority of burials interred with two, or less frequently, one category of object. Instances of the former are all from northern cemeteries, but the profile of the Sewerby community is less pronounced in this way than Scorton or Castledyke South. By contrast, the other northern cemetery-West Heslerton-aligns more closely with that of southern communities, Mill Hill, Deal in particular.

Breaking the figures down further, some of these distinctions are less apparent, while others are starker (Tab 6). All communities have a relatively even split between 'simpler' (0-2 categories of objects) and 'more complex' (3-5/6 categories) members of the community, at a ratio of about 7:3. At the 'more complex' end of these profiles, there is little distinction in the profile between any of the communities in the sample. Scorton has the smallest proportion of 'more complex' graves overall (20.3\%); Market Lavington the most (35.7\%). When the definition of 'more complex' is narrowed to graves with only 4-5 categories of objects, the distinctions between communities effectively disappears. If this calculation can in some ways be equated with an 'apex group', it appears that this was comparable in every community in both size and material expression - a factor that may indicate some level of mutual, supra-regional determination.

Greater variability between communities is visible amongst the 'simpler' burials, i.e. those with 0-2 categories of objects. At Scorton and Castledyke South the majority of burials were interred with no objects in any category and a decreasing number had 1 or 2. At Mill Hill, Deal, Market Lavington and West Heslerton this tendency is reversed, with a majority having two categories of objects.

While we can only compare the material investment in graves that has survived, at least in terms of the archaeologically visible categories used here, northern communities seem to have been less likely to invest in the grave at death, especially in terms of metalwork. The site that stands apart from this is West Heslerton where investment in terms of goods is more on a par with the southern cemeteries. However, in each case there is a more complex group who at death were in invested by the living with more elaborate assemblages, by comparison with their deceased neighbours, perhaps pointing to similar emergent intra-group processes of social stratification articulated via display at death. Within this group, investment is particularly evident in relation to certain groups, such as adults and females.

\section{DISCUSSION}

There are hints at regional trends in the constituent elements of the inhumation process, but these are equivocal. Northern and southern communities are distinctive in aspects of grave theatre such as grave orientation, and to a lesser degree body position and object categories, but there are also, in some respects, significant differences between east and west and between neighbouring communities, so that individual communities in the north might in some ways appear less regionally distinctive as a collective group. From the perspective of object categories, for example, the distribution of grave goods interred with the community at West Heslerton is remarkably similar to that of Mill Hill, Deal or Market Lavington, even if in grave orientation or body position it shares closer affinities with neighbouring cemeteries in the North. By way of contrast, burial norms at Mill Hill, Deal are more consistently applied and thereby distinctive from the pattern visible elsewhere.

Comparison of the data show few clear-cut patterns. If the number of object categories is regarded as demonstrating a form of social division, it is telling that there are limited distinctions 
between individuals buried with 0 object categories and those with 4-5 in terms of the grave shape, age band of the individual, or body position. There is a tendency for poorly-furnished burials to be orientated NW-SE and W-E, but they are no more likely to be crouched, prone, or sub-adult than more complex burials, as one might at first suppose. Individuals with 4-5 object categories have on average both more and less grave space than those with none; but are likely also to be adults laid out supine in a manner that might lend itself better to the arrangement of objects around the burial. Some trends, although fairly weak, may, however, carry some significance in terms of social differentiation: notably that adult burials are more likely to have 4-5 object categories and so are female burials.

It is possible to argue that each burial was a unique piece of theatre in which a range of choices and decisions were deployed. Whether these aspects of mortuary practices genuinely build up to a bigger picture of community burial choices is merits further investigation. In this regard, the uniformity of the burial ritual at Mill Hill, Deal, Kent stands out. Here, more normative ideas of society appear to have been communicated in such a way that they impacted on mortuary practices. It remains to be seen whether this site is representative of others in the early Kentish kingdom, but taken on its own it is possible that this conformity to a narrow suite of burial norms reflects a more widespread regional behaviour in which tighter social controls over mortuary expression were expressed, something argued for in terms of body positioning more broadly. Alternatively, although not mutually exclusive, the consistency at Mill Hill could be argued as demonstrative of a stronger community identity played out within the funerary sphere. Other analyses have suggested the existence in eastern Kent of relatively homogenous practices in the consumption of material wealth in burial, potentially related to the emergence, already in the sixth century, of supra-local identities (Brookes 2007, 146-56). Applying our analogy, the social and political theatre of burial in this community might reflect this same development of a society in which normative practice was being encouraged as an element in the construction of a supra-regional sense of identity and belonging, even before the advent of more normative Christian burial practices in the seventh and eighth centuries. The greater coherence of mortuary management, evident at Mill Hill, Deal, might also imply a longer tradition of community managed mortuary practice and a stricter set of protocols for disposal and funerary theatre.

Amongst the great variety of burial forms exhibited at these sites there are hints of more homogenous practices and norms that cut across local diversity. The apparently even proportions of well-furnished burials - by object categories - in each of the communities examined here, may be taken as evidence for the emergence of more widespread behaviour in which a distinctive class of burial persona was expressed. Potentially, categories of objects were used to construct differences between individuals. Adult and female burials with $4+$ categories were more prevalent in the dataset, suggesting that some of the differentiation present in the funerary theatre might be connected with the human life course and the individual rather than merely wealth or social standing. On a site-by-site basis there are also indications that certain age categories were afforded more space in the grave, perhaps to accommodate goods and materials we can no longer see archaeologically. This tells us something, perhaps, of the varied social and sacred needs and rites of disposal that developed and became inherent within communities and that came to serve as bonds and signals of a collective notion of identity.

But, can the ideas behind the object categories be used to inform on ideas about the person? For example, how might we interpret the evidence that weapon burials do not score consistently high in the full number of object categories? Only one weapon grave has objects from the other five categories; the majority (79\%) have only 1-3 categories of objects, including weaponry (Tab 7). If weapon burials represent those at the apex of their communities, why did mourners not access the full range of possible categories of grave furnishing? These findings raise questions over 
the general tendency to infer status and hierarchy from types and quantities of objects, grave complexity and monumentality.

Clearly, in death at least, the signalling of social power and status was not just about diversity in terms of goods or indeed about making a large and elaborate display. Perhaps weapons alone carried sufficient significant symbolic and social value, to the extent perhaps that they were more likely in the north to be retained in use rather than deposited. Similarly, the normative view would suggest that those without any goods or with just one item were 'poorer' or less well regarded in their communities, but their grave shapes and body positions as demonstrated here are consistent with the overall pattern suggesting no less investment in these aspects of mortuary behaviour by the living. A range of ideas about the correct forms of mortuary expression were clearly in circulation at the same time across these geographic areas, but communities differed in how they participated in these protocols and in the north divergences are evident between and within cemeteries, suggestive of much less emphasis on conformity in the burial arena than in their southern counterparts. The norms detected here suggest there were shared conceptions of particular rites relevant to all that were necessary to successfully transform the body of the deceased to a venerated ancestor. Yet in this context the more varied mortuary activity evident in the four northernmost cemeteries presents an interesting divergence, worthy of further exploration. Even at West Heslerton, where material investment in terms of grave goods is on a par with southern sites in terms of orientation, grave size and body positioning, inhumation practices lack the kinds of conformity evident at Mill Hill, Deal. Less regularized mortuary practices can be inferred perhaps and less central management, but this evidence might also be read in terms of the social groups themselves, who felt under less constraint in terms of identifying with a strict package of mortuary behavior, or indeed, defined themselves by means of more variable rites and practices. While such findings need to be explored across the larger dataset, this evidence may be significant for understanding levels of community cohesion and by default the processes of community formation. Regarded in this way the choices by individual communities in these cemeteries may imply they were more accepting of difference and willing to acknowledge and accommodate a variety of mortuary expressions and some were in less need of, or maintained less coherent, signalling mechanisms at the funeral, relevant to the maintenance of group identity and holding local power in the southern regions. This broad scale assessment also strongly suggests political gain and status were just elements within a far richer and bespoke mortuary theatre. The variations in framing, performance and acts of grave closure in the north and south speak to differences in the fundamental concerns and beliefs of living families and communities about death and their acts of investment at the graveside.

\section{CONCLUSION}

It has long been recognised that mortuary practices in early medieval Britain and Europe demonstrate exceptional diversity and yet in the fifth and sixth centuries in the communities bordering the North Sea coasts the funerary theatre implies that people were actively seeking and exploring commonalities in the ways they disposed of the dead. While migration in southern and eastern Britain clearly brought new ideas and concepts of disposal, these were not embraced wholesale: instead a process of negotiation and hybridisation resulted in striking bottom-up responses to social change that were expressed materially in many media, but particularly in the funerary theatre. The grave and the acts of closure, however small or subtle, performed within and around the body in the performance of inhumation rites provided opportunities for constructing and signalling individual and group narratives of identity. While some moved towards inhumation with grave goods, in these cemeteries many were buried either with nothing or with material that has not left clear archaeological traces. In past and current narratives these individuals are often overlooked 
and we believe they deserve attention as part of a more holistic methodology for exploring past buried populations. Even unfurnished inhumation graves provide some material basis for exploring the acts or rites of passage enacted by mourners as they sought to enable the safe transition of the deceased from life to death.

We have sought, therefore, to look for the nuance in published archaeological data regarding cemeteries, turning away from traditional viewpoints that emphasise goods, metalwork and grave-furniture. Instead, taking examples from north and south, we have sought to compare the more innate aspects of burying the dead that still represent human investment and have a capacity for informing us about localised and regional trends in the way communities dealt with death. For many years ideas of ethnicity and identity have been explored largely via furnished burial rites or monumentality: this paper has sought to redress this emphasis, by focusing on the underexploited yet recorded aspects of funerary ritual that include grave size, shape and orientation, space in the grave and the lack or presence of assemblages, rather than the detail of the objects included. Our aim has been to interrogate the attributes of funerary ritual that might be governed by the many rather than the few: those processes inherent to how families and communities dealt with their dead irrelevant of status, operating within the rules they imposed on themselves and each other.

The cemeteries considered here are but a sample of those engaged with in the underpinning research projects that contributed data, yet we are still drawing our evidence from some 880 individual people who experienced life and died in the fifth and sixth centuries AD. Rather than exploring specifics, we have chosen to focus on the stages of mortuary theatre that all communities must have shared, the choices of where to bury and how, what to give or withhold, how to memorialise or not. These actions speak to us about the sheer variety of ways in which their relatives or communities chose to invest in the act of inhumation burial and by picking apart the processes of interment we can gain insights into ontological understandings of death and the ways in which families and communities chose to share or differentiate activity at the graveside.

There are notable commonalities and differences here in how these contemporary communities operated at the funeral, separated in many cases by hundreds of kilometres. The basic commonalities of choosing a grave location and excavating a grave are unanimous facets in the funerary activities of these populations. Grave orientation was variable in the north suggesting this was less managed or less significant for these populations, although a low-level, but persistent, frequency of $\mathrm{E}-\mathrm{W}$ burial in these cemeteries could perhaps signal stronger adherence by some to inherited Roman-British traditions. The distinct shared orientations in the south suggest that while multiple influences may have been at play, that norms where established and adhered to. In terms of grave morphology, body position and space, grave shape varied from site to site, as did the space afforded to the dead, but body positioning followed more coherent patterns in the southern cemeteries than in the north.

The overall variabilities present in disposal methods are striking. Northern communities seem to have had reasons to operate outside the social constraints evident in the south-east. In the north, different norms were operating that demonstrate greater variability and experimentation. This is expressed to in the categories of object included with individuals at death. In the south, when weapons were present, these seem to have circumscribed any other material offerings at death. They tend to stand alone, perhaps suggesting that such categories on their own sufficiently signified the social roles of the interred. In the north weapons-whilst rare-were as likely to be combined with other object categories so that a defined martial identity was less clearly articulated. The trend for lower numbers of objects in graves in the northern cemeteries could signal less access to certain types of material or objects were kept in circulation rather than being disposed of in the grave or that larger quantities of organic (and now invisible) goods were included with the deceased. At Sewerby, young adults seem to have been afforded more space in the grave and across all of the 
cemeteries studied. This might perhaps confirm that either certain types of goods were less accessible to certain regions or groups within communities, or were maintained in circulation, but these findings could also signal that larger quantities of, now invisible, organic goods, were part of northern disposal patterns. It is worth considering as well, however, that this might also demonstrate how individual communities nuanced their rites of disposal in relation to particular moments in the life course or categories of individual. More broadly the graves of younger individuals contained greater amounts of space, notwithstanding the smaller body mass of the deceased. This could indicate a greater investment in the graves of the young in, now absent, organic goods. Similarly, while object categories were less prevalent in northern graves, overall object categories were more plenteous in adult and in female graves, underlining that irrelevant of region or accessibility of goods for funerary use, populations nuanced their approaches to individuals based on the time of life and sex of the individual and, we might assume, the significance of the deceased for the living community.

Whether in the north or south, it seems these populations were engaging in complex and intentional choices and processes around the death and disposal of members of their communities. Their actions express common norms and cross-cutting investments that go beyond any simple explanation of status or wealth. There are commonalities across all regions, conveying that these populations were participating to greater and lesser extents in a common repertoire of necessary rituals for disposal, aimed at safely conveying the deceased from the world of the living to an ancestral status for that community. Differences in north and south should neither be overlooked, nor explained in a limiting way as simply indications of the relative wealth, status and political power of these populations. There is potential here to view the variability in terms of levels of community and regional coalescence and identity. The comparatively striking absence of strong signs of mortuary uniformity in the north might reflect a level of empowerment and freedom from regional and top-down political constraints. The independence expressed may also be indicative of different modes of social obligation at death and different ontologies for handling the transcendence of the deceased from the world of the living. There are also clear indications of meaningful investment at a community level that cross-cut the regional scene. Some communities invested in certain age groups and in those that died at a particular point in the life course. These finding also underline the risks in relying on object type and the quantity of object categories alone as inferences of power, status and social hierarchy.

Here we show that communities living in similar environments differed from one another in how they performed funerary rituals and disposed of the dead, yet drew from a common 'inhumation template'. Some adhered to more scripted forms of behaviour at the funeral than others, such as the community at Mill Hill, Deal. Some burying communities, like those at Sewerby and Scorton seem to have had more ability to signal difference and this might just be indicative of a greater fluidity in the mechanisms by which communities were defining themselves using the mortuary theatre. We have been able to illuminate local adaptations to the problems of burial, but also demonstrated the potential of large-scale analysis for teasing out modes of display and performance in the 'theatre of closure' at the graveside that give insight into the crystallising processes of individual and group display relevant to emergent communal, political and ideological identities.

By taking a broader view than just a local or regional perspective we have been able to compare acts of inhumation disposal across communities and regions. This is just a start, but it shows the value of digitally interrogating larger datasets and focusing on all aspects of the funerary process rather than objects alone. Arguably these observations provide a significant counter to older models and approaches which have put significant emphasis on using cemeteries and graves to underpinning arguments for social complexity, elite status and hierarchical social structures. The 
evidence here allows these communities far more autonomy and choice and implies a level of ability to participate, or not, in the broader ideological packages surrounding death and burial. It also underlines that optionality as well as adherence may be defining elements in processes of social coalescence and equal contributors in the forging of group identity.

\section{References}

Banham, D. and Faith, R. 2014. Anglo-Saxon farms and farming. Oxford: Oxford University Press. Bhreathnach, E. et al. 2010. http://www.mappingdeathdb.ie/login [accessed Feb 2018]

Blair, J. 2009. The dangerous dead in early medieval England. In Baxter, S., Karkov, C., Nelson, J.L, and Pelteret, D. (eds.) Early Medieval Studies in Memory of Patrick Wormald. Ashgate: Farnham, 539-59

Boyle, A. et al 1998. The Anglo-Saxon cemetery at Butler's Field, Lechlade, Gloucestershire. Oxford, Oxford Archaeological Unit.

Brookes, S. 2007. Economics and Social Change in Anglo-Saxon Kent AD 400-900. Landscapes, communities and exchange. BAR British Series 431. Oxford, British Archaeological Reports.

Brookes, S. and Harrington, S. 2008. The Anglo-Saxon Kent Electronic Database. ADS Special Collections: http://ads.ahds.ac.uk/catalogue/archive/asked ahrc 2008/

Brookes, S. and Harrington, S. 2013. Electronic Census: enhancing or masking individuality in the early Anglo-Saxon past? In B. Ludowici (ed.), Individual and Individuality. Approaches towards an Archaeology of Personhood in the First Millennium AD. Neue Studien zur Sachsenforschung 4, 21-6.

Harrington, S. and Brookes, S. 2019. Beyond the Tribal Hidage Data. https://www.ucl.ac.uk/earlymedieval-atlas/map-data/beyond-tribal-hidage-data

Brookes, S., Harrington, S. and Welch, M. 2006. Documenting the dead: creating an on-line census of Anglo-Saxon burials from Kent. Archaeology International 2005/2006, 28-31.

Carver, M. O. H. 1998. Sutton Hoo: Burial Ground of Kings. London, British Museum Press

Carver, M. O. H. 2000. Burial as poetry: the context of treasure in Anglo-Saxon graves. In E. M. Tyler (ed.) Treasure in the Medieval West. York, York Medieval Press, 25-48

Carver, M. O. H. 2005. Sutton Hoo: A seventh-century princely burial ground and its context. Reports of the Research Committee of the Society of Antiquarians in London no. 69. London: British Museum Press.

Chavarría Arnau, A. 2019. Early Medieval Burials and settlements: some reflections on Northern Italian archaeological evidence. In Escalona, J., Vésteinsson, O. and S. Brookes (eds.) Polity and Neighbourhood in Early Medieval Europe. Turnhout: Brepols, 83-120

Chavarría Arnau, A. and Brogiolo, G. 2013: http://www. beniculturali.unipd.it/www/ricerca/linee-diricerca/progetto-camis-cimiteri-altomedievali-dellitalia-settentrionali/ [accessed Feb 2018]

Craig, E. 2010. Burial practices in Northern England c A.D. 650-850: A bio-cultural approach. Unpublished PhD thesis, University of Sheffield.

Drinkall, G. and Foreman, M. 1998. The Anglo-Saxon cemetery at Castledyke South, Barton-onHumber. Sheffield Excavation reports, 6. Sheffield: Sheffield Academic Press.

Duday, H., 2009: The archaeology of the dead. Lectures in Archaeothanatology. Studies in Funerary Archaeology Vol. 3. Oxbow: Oxford and Oakville.

Evison, V.I. 1987. Dover: The Buckland Anglo-Saxon Cemetery. London: Historic Buildings \& Monuments Commission for England Archaeological Report 3.

Filmer-Sankey and Pestell 
Foreman, M. 1998. Mortuary practices. In G. Drinkall and M.Foreman, M.The Anglo-Saxon cemetery at Castledyke South, Barton-on-Humber. Sheffield Excavation reports, 6. Sheffield: Sheffield Academic Press.

van Gennep, A. The Rites of Passage. London and New York: Routledge.

Gilchrist, R. and Sloane, B. 2005. Requiem: the medieval monastic cemetery in Britain. London: Museum of London Archaeology Service

Halsall, G. 2003. 'Burial Writes: Graves, Texts and Time in Early Merovingian Northern Gaul', in J. Jarnut and M. Wemhoff (eds), Erinnerungskultur im Bestattungsritual (Munich, Wilhelm Fink, 2003), pp. 61-74

Härke, H. 1990. "'Warrior Graves". The Background of the Anglo-Saxon Weapon Burial Rite', Past and Present, 126 (1990), 22-43

Harrington, S. 2007. Soft Furnished Burial. Anglo-Saxon Studies in Archaeology and History 14, 11016

Harrington, S. and Welch, M. 2014. The Early Anglo-Saxon Kingdoms of Southern Britain AD 450 650: Beneath the Tribal Hidage. Oxford: Oxbow

Haughton, C. and Powlesland, D. 1999. West Heslerton: the Anglian cemetery. Yeddingham, North Yorkshire: Landscape Research Centre.

Hawkes, S. C. 1976. Orientation at Finglesham: sunrise dating of death and burial at an Anglo-Saxon cemetery in East Kent. Archaeologia Cantiana 92, 33-51

Hawkes, S. C. 1982. Anglo-Saxon Kent c.425-725. In P. Leach (ed), Archaeology in Kent to 1500: 6478. London: Council for British Archaeology Res. Rep.48.

Hawkes, S.C. and Grainger, G. 2006. The Anglo-Saxon Cemetery at Finglesham, Kent. Oxford: Oxford University School of Archaeology Monograph 64.

Hirst, S.M. 1985. An Anglo-Saxon Inhumation Cemetery at Sewerby, East Yorkshire. York: York University Archaeological Publications 4

Klevnäs, A. M. 2013. Whodunnit? Grave Robbery in Anglo-Saxon England and the Merovingian Kingdoms. Oxford, BAR International Series 2582.

Knüsel, C. and Outram, A. 2009. Fragmentation of the body: comestibles, compost or customary rite? In R. Gowland and C. Knüsel (eds) Social archaeology of funerary remains, 253-278. Oxford: Oxbow Books

Leclerc, J., 1990. La notion de sépulture. Bulletins et Mémoires de la Société d'Anthropologie de Paris, N.S. 2.3-4, 13-18.

Lucy, S. 2000. The Anglo-Saxon way of death. Stroud: Sutton Publishing Ltd

Maldonado, A. 2011. What does early Christianity look like? Mortuary archaeology and conversion in Late Iron Age Scotland. Scottish Archaeological Journal 33 (1-2), 39-54

Maldonado, A. 2013. Early medieval burial in Scotland: new questions. Medieval Archaeology 57 (1), 1-34.

Manning, W.H. 1985. Catalogue of the Romano-British iron tools, fittings and weapons in the British Museum. London, British Museum Publications Ltd.

Mortimer, R., Sayer, D. and Wiseman, R. 2017. Anglo-Saxon Oakington: A Central Place on the Edge of the Cambridgeshire Fen. In S. Semple, C. Orsini and S. Mui (eds), Life on the Edge: Social and Political Frontiers in Early Medieval Europe. Neue Studien zur Sachsenforschung 6. Braunschweigisches Landesmuseum, pp. 305-16.

Mui, S., 2015. Life after death: Shrouded burials in later Anglo-Saxon England. Archaeological Review from Cambridge 30 (1), 150-156.

Mui, S., 2018. Dead Body Language: deciphering corpse positions in Early Anglo-Saxon England. Unpublished PhD Thesis, Durham University.

NAA 2002 unpublished report Excavations at Hollow Banks Quarry, Scorton, North Yorkshire 
Pader, E-J. 1982. Symbolism, Social Relations and the Interpretation of Mortuary Remains. Oxford: BAR International Series 130

Parfitt, K. and Brugmann, B. 1997. The Anglo-Saxon cemetery on Mill Hill, Deal, Kent. Society for Medieval Archaeology monograph series no. 14. London: Society for Medieval Archaeology.

Petts, D. 2002. Cemeteries and boundaries in western Britain. In S. Lucy and A. Reynolds Burial in early medieval England and Wales, 24-46. Society for Medieval Archaeology Monograph Series 17. Leeds: Society for Medieval Archaeology.

Price, N. 2010. Passing into poetry: Viking-Age mortuary drama and the origins of Norse mythology. Medieval Archaeology 54: 123-156.

Roberts, C. 2014. Human remains. In J. Balme and A. Paterson (eds) Archaeology in Practice. A Student Guide to Archaeological Analyses, 300-335. Oxford: Wiley Blackwell.

Roberts, C. and Cox, M. 2003. Health \& disease in Britain: from prehistory to the present day. Gloucester: Sutton Publishing.

Samson, R. 1987. Social Structures from Reihengräber: mirror or mirage? Scottish Archaeological Review 4.2, 116-126

Sayer, D. and Wienhold, M. 2013. A GIS-investigation of Four Early Anglo-Saxon Cemeteries: Ripley's K-Function analysis of spatial groupings amongst graves. Social Science Computer Review 31(1), 70-88

Semple, S. and Williams, H. 2015. Landmarks for the dead: exploring Anglo-Saxon mortuary geographies. In M. Clegg Hyer and G. R. Owen-Crocker (eds) The Material Culture of the Built Environment in the Anglo-Saxon World, Vol. II of The Material Culture of Daily Living in the Anglo-Saxon World, Liverpool: Liverpool University Press, pp. 137-61

Semple, S., Buchanan, B., Harrington, S., Oliver, D. and Petts, P. 2017. Power at the Edge: Yeavering, Northumberland, England. In S. Semple, C. Orsini and S. Mui (eds), Life on the Edge: Social and Political Frontiers in Early Medieval Europe. Neue Studien zur Sachsenforschung 6. Braunschweigisches Landesmuseum, pp. 91-112.

Williams, H. 2001. Death, Memory and Time: A Consideration of the Mortuary Practices at Sutton Hoo. In C. Humphreys and W. M ormrod (eds), Time in the Medieval World, York Medieval Press, 35-71.

Williams, H. 2006. Death and Memory. Cambridge: Cambridge University Press

Williams, H. 2011 Williams, H. 2011. Archaeologists on Contemporary Death, Mortality 16(2): 91-7. http://dx.doi.org/10.1080/13576275.2011.560450

Williams, P. and Newman, R. (eds). 2006. Market Lavington, Wiltshire, an Anglo-Saxon cemetery and settlement, excavations at Grove Farm, 1986-90. Wessex Archaeology Report no. 19. Salisbury, Wessex Archaeology Ltd.

\section{Acknowledgements}

We are grateful to Elizabeth Byron, Lauren Harvey, and Victoria Ziegler who helped with the digitisation of hundreds of individual grave plans. Thanks as well to Dr Robert Collins for valuable input during the development of the paper.

\section{Figure Captions}

Figure 1a: Grave plans from Finglesham Anglo-Saxon cemetery, Kent (reproduced from Hawkes and Grainger 2006, fig. 2.43)

Figure $1 \mathrm{~b}$ : Cemetery plan showing the early graves at Wearmouth, Durham (reproduced from Cramp 2005, vol 1, fig 8.3).

Figure 2: Location of burial sites mentioned in the text

Figure 3: Radar plots of the relative frequency of burial orientations 
Figure 4: Percentage frequency of grave shapes

Figure 5: Percentage frequency of body positions

Figure 6: Volumetric analysis of graves is complicated by a number of factors: a) the degree that graves have been truncated after burial, b) whether the grave cut was vertical or sloped, c) the horizontality of the surface and base of the grave cut. To mitigate against the effects of these unknown coefficients, two-dimensional area analysis was calculated in this analysis as a proxy for 'volume' by deducting the area of the body ' $A$ ' from that of the grave ' $A 1$ '.

Figure 7a: Average grave size and the percentage of empty space.

Figure 7b: Percentage of empty space by age band. Nb. Bone survival at Scorton, Yorkshire, was too insufficient to include Scorton in this calculation.

Figure 8: Percentage frequency of object categories 
Table 1 Selected cemetery sites.

\begin{tabular}{|c|c|c|c|}
\hline Site & County & Cemetery Details & Reference \\
\hline West Heslerton & East Yorkshire & $\begin{array}{l}\text { Large mixed rite cemetery (200) within an } \\
\text { intensively occupied area of Anglian } \\
\text { settlement in the Vale of Pickering. The } \\
\text { publication includes grave plans and } \\
\text { photographic images of each burial. } \\
\text { Radiocarbon dates have confirmed the date } \\
\text { range. }\end{array}$ & $\begin{array}{l}\text { Haughton and } \\
\text { Powlesland } 1999\end{array}$ \\
\hline Sewerby & East Yorkshire & $\begin{array}{l}\text { Small inhumation cemetery (60) near } \\
\text { Bridlington that connects with other } \\
\text { communities along the east coast of England. } \\
\text { The publication has been used as a standard } \\
\text { text in university courses through its } \\
\text { discussions of the range of attributes within } \\
\text { such cemeteries. }\end{array}$ & Hirst 1985 \\
\hline $\begin{array}{l}\text { Hollow Banks, } \\
\text { Scorton }\end{array}$ & & $\begin{array}{l}\text { Mixed rite cemetery (123) which lies inland } \\
\text { near the main north-south Roman road (Dere } \\
\text { Street) as it passes Catterick and also on a } \\
\text { major east-west route through the Pennines. } \\
\text { It is on the western edge of the kingdom of } \\
\text { Deira and includes a small series of Late } \\
\text { Roman inhumations with confirmed } \\
\text { radiocarbon dates. }\end{array}$ & $\begin{array}{l}\text { NAA } 2002 \\
\text { unpublished }\end{array}$ \\
\hline Castledyke South & $\begin{array}{l}\text { South } \\
\text { Humberside }\end{array}$ & $\begin{array}{l}\text { Inhumation cemetery (154) overlooking a } \\
\text { crossing point of the River Humber and on a } \\
\text { liminal position with regard to Northumbria } \\
\text { and the southern Anglian polities. }\end{array}$ & $\begin{array}{l}\text { Drinkall and } \\
\text { Foreman } 1998\end{array}$ \\
\hline $\begin{array}{l}\text { Butler's Field } \\
\text { Lechlade }\end{array}$ & Gloucestershire & $\begin{array}{l}\text { Large mixed rite cemetery (219) at the } \\
\text { western end of the early Anglo-Saxon zone of } \\
\text { settlement in southern Britain, situated } \\
\text { above the major regional conduit, the River } \\
\text { Thames. It continues into the seventh century } \\
\text { and exhibits a range of regional and cultural } \\
\text { connections, primarily Saxon with some } \\
\text { Kentish influences later. }\end{array}$ & Boyle et al. 1998 \\
\hline $\begin{array}{l}\text { Grove Farm, } \\
\text { Market Lavington }\end{array}$ & Wiltshire & $\begin{array}{l}\text { The inhumation cemetery of a small Saxon } \\
\text { agrarian community on the western edge of } \\
\text { the early Anglo-Saxon zone of settlement ( } 42 \\
\text { burials but only } 19 \text { grave cuts recordable). }\end{array}$ & $\begin{array}{l}\text { Williams and } \\
\text { Newman } 2006\end{array}$ \\
\hline Mill Hill, Deal I & Kent & $\begin{array}{l}\text { Richly furnished and important inhumation } \\
\text { cemetery (81) on the south coast near to } \\
\text { Dover, the closest crossing point to the } \\
\text { Continent. It exhibits a range of material } \\
\text { culture influences including Merovingian. }\end{array}$ & $\begin{array}{l}\text { Parfitt and } \\
\text { Brugmann } 1997\end{array}$ \\
\hline
\end{tabular}


Table 2 Quantitative and qualitative information collated and analysed for the chosen cemeteries.

\begin{tabular}{|l|l|l|}
\hline Cemetery Attribute & Type of Evidence & Definition \\
\hline $\begin{array}{l}\text { Architecture and } \\
\text { staging: locating and } \\
\text { creating the grave }\end{array}$ & Grave orientation & $\begin{array}{l}\text { Decision made in terms of cutting and } \\
\text { orienting the grave ready for the inhumation }\end{array}$ \\
\cline { 2 - 3 } & Grave morphology & $\begin{array}{l}\text { Decision on the size of the grave cut and how } \\
\text { it might accommodate the body and any other } \\
\text { material }\end{array}$ \\
\hline The Body & Body position & $\begin{array}{l}\text { Decision on how to place the body/ies in the } \\
\text { grave-space }\end{array}$ \\
\hline \multirow{2}{*}{ Props/or furnishings } & Material culture & $\begin{array}{l}\text { Assessment of the surviving material culture } \\
\text { through a process of categorisation }\end{array}$ \\
\cline { 2 - 3 } & Grave-space & $\begin{array}{l}\text { Presence and quantification of any apparent } \\
\text { space around the body }\end{array}$ \\
\hline
\end{tabular}

Table 3 Grave shape descriptors

\begin{tabular}{|l|l|}
\hline Category & Description \\
\hline Regular & Both sets of opposing sides of the cut are symmetrical to one another \\
\hline Semi-regular & $\begin{array}{l}\text { One set of opposing sides are symmetrical (this includes pear shaped graves and ones } \\
\text { where one end is straight and the other rounded but opposing long sides are similarly } \\
\text { shaped) }\end{array}$ \\
\hline Irregular & Nothing symmetrical about the shape although elongated \\
\hline
\end{tabular}

Table 4 Categories of body position defined for the purpose of this comparative study.

\begin{tabular}{|c|c|}
\hline Crouched & $\begin{array}{l}\text { Body is on its side in a contracted position, where the angle between the thighs } \\
\text { and the body is less than } 90^{\circ} \text { and the degree of flexion of the lower limbs is less } \\
\text { than } 45^{\circ} \text { - below included in this category. } \\
\text { - Crouched (right) - body on its right side } \\
\text { - Crouched (left) - body on its left side }\end{array}$ \\
\hline Flexed & $\begin{array}{l}\text { Upper torso is on its back flat against the ground, but with the legs bent to one } \\
\text { side }\end{array}$ \\
\hline Left-side extended & $\begin{array}{l}\text { Laid out on the left side. This also includes those with a slight degree of flexion in } \\
\text { the legs }\end{array}$ \\
\hline Right-side extended & $\begin{array}{l}\text { Laid out on the right side. This also includes those with a slight degree of flexion } \\
\text { in the legs }\end{array}$ \\
\hline Prone & $\begin{array}{l}\text { Face down in the grave The body may be in a variety of positions, including semi- } \\
\text { crouched, but the determining element is that the face is down into the grave } \\
\text { cut }\end{array}$ \\
\hline
\end{tabular}




\begin{tabular}{|l|l|}
\hline Supine & $\begin{array}{l}\text { Laid out extended on the back. The position of the legs may vary, for example } \\
\text { crossed at the ankles or splayed. Issues such as whether the body was bound or } \\
\text { swaddled are not addressed here. }\end{array}$ \\
\hline
\end{tabular}

Table 5 Six categories of grave object

\begin{tabular}{|l|l|}
\hline $\begin{array}{l}\text { Grave } \\
\text { equipment }\end{array}$ & coffin, bier etc. \\
\hline Dress fitments & buckles, brooches \\
\hline Containers & $\begin{array}{l}\text { boxes, ceramic vessels, copper alloy bowls, } \\
\text { glass vessels }\end{array}$ \\
\hline Weaponry & swords, shields, spears, seaxes \\
\hline Tools & spindle whorls, awls \\
\hline Personal effects & combs, beads (glass or other material), knives \\
\hline
\end{tabular}

Table 6 Attribute correspondence with burials containing most and least object categories

\begin{tabular}{|c|c|c|c|c|c|c|c|c|c|c|c|c|c|c|c|c|c|c|c|c|c|c|c|c|c|c|c|c|c|c|c|}
\hline \multirow{2}{*}{\begin{tabular}{|c|}
$\begin{array}{c}\text { No of } \\
\text { object } \\
\text { categories }\end{array}$ \\
\end{tabular}} & \multirow[t]{2}{*}{\begin{tabular}{|c|}
$\begin{array}{c}\text { No of } \\
\text { graves }\end{array}$ \\
\end{tabular}} & \multicolumn{4}{|c|}{$\begin{array}{c}\text { Grave } \\
\text { shape (\%) }\end{array}$} & \multicolumn{3}{|c|}{\begin{tabular}{|l|} 
Voids (\%) \\
\end{tabular}} & \multicolumn{2}{|c|}{ Sex (\%) } & \multicolumn{7}{|c|}{$\begin{array}{c}\text { Age } \\
\text { band (\%) }\end{array}$} & \multicolumn{6}{|c|}{$\begin{array}{l}\text { Position of } \\
\text { body (\%) }\end{array}$} & \multicolumn{8}{|c|}{$\begin{array}{c}\text { Grave } \\
\text { orientation (\%) }\end{array}$} \\
\hline & & 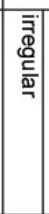 & 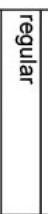 & 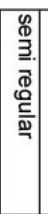 & 촗 & 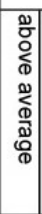 & $\sum_{0}^{\overline{0}}$ & 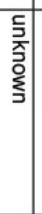 & $\begin{array}{l}\text { 勇 } \\
\frac{\vec{\omega}}{\omega} \\
\end{array}$ & & 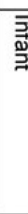 & 을 & \begin{tabular}{|l|l} 
& $\bar{\hbar}$ \\
$\mathbf{\Phi}$ \\
$\overline{\bar{\omega}}$ \\
\end{tabular} & 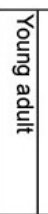 & $\begin{array}{l}\stackrel{\vec{a}}{c} \\
\stackrel{\equiv}{=}\end{array}$ & 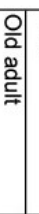 & & 彦 & 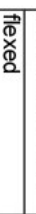 & 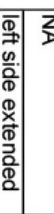 & $\begin{array}{l}\mathrm{o} \\
\text { o } \\
\text { के }\end{array}$ & 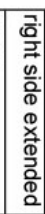 & $\begin{array}{c}\frac{c}{c} \\
\bar{c} \\
\overline{\bar{\sigma}}\end{array}$ & 紊 & $\sum^{m}$ & 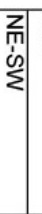 & & & & & \begin{tabular}{|l|}
$\mid$ \\
n
\end{tabular} \\
\hline 0 & 112 & 21 & 29 & 34 & 16 & 20 & 24 & 56 & 162 & \begin{tabular}{l|l}
20 & 64
\end{tabular} & 7 & \begin{tabular}{|l|} 
\\
\end{tabular} & 11 & 6 & 32 & 6 & 2 & 3 & 16 & \begin{tabular}{l|l}
4 & 46
\end{tabular} & 5 & 5 & 21 & 4 & 4 & 4 & \begin{tabular}{l|l}
4 & 3
\end{tabular} & \begin{tabular}{l|l}
30 & 6
\end{tabular} & 3 & 19 & 26 \\
\hline 4 to 5 & 40 & 21 & 35 & 44 & 0 & 42 & 38 & 20 & 433 & \begin{tabular}{l|l}
34 & 23 \\
\end{tabular} & 0 & 3 & 5 & 15 & 58 & 15 & 4 & 0 & 18 & \begin{tabular}{l|l}
3 & 10 \\
\end{tabular} & 3 & 5 & 61 & 0 & 3 & 0 & \begin{tabular}{l|l}
4 & 1
\end{tabular} & \begin{tabular}{l|l}
15 & 7
\end{tabular} & 5 & 48 & 18 \\
\hline
\end{tabular}

Table 7 Individuals with weaponry relative to numbers of object categories, split by northern and southern communities

\begin{tabular}{|l|l|l|l|}
\hline No of object categories & No of individuals & Northern & Southern \\
\hline 6 & 1 & 1 & 0 \\
\hline 5 & 7 & 1 & 6 \\
\hline 4 & 10 & 4 & 6 \\
\hline 3 & 36 & 21 & 15 \\
\hline 2 & 30 & 10 & 20 \\
\hline 1 & 7 & 5 & 2 \\
\hline
\end{tabular}



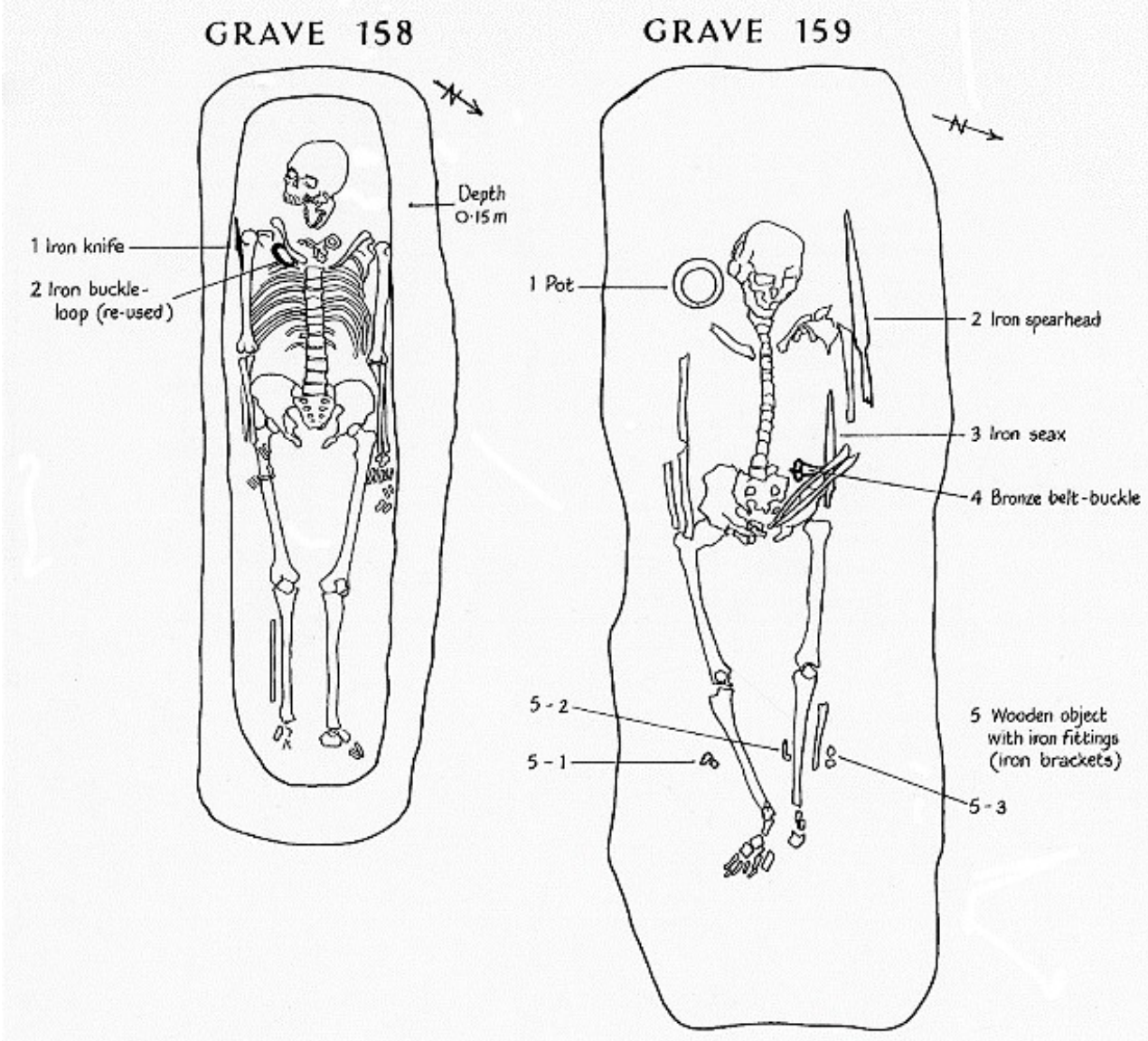

Figure 1 a. Grave plans from Finglesham Anglo-Saxon cemetery, Kent (reproduced from Hawkes and Grainger 2006, fig. 2.43;

$72 \times 68 \mathrm{~mm}(220 \times 220 \mathrm{DPI})$ 


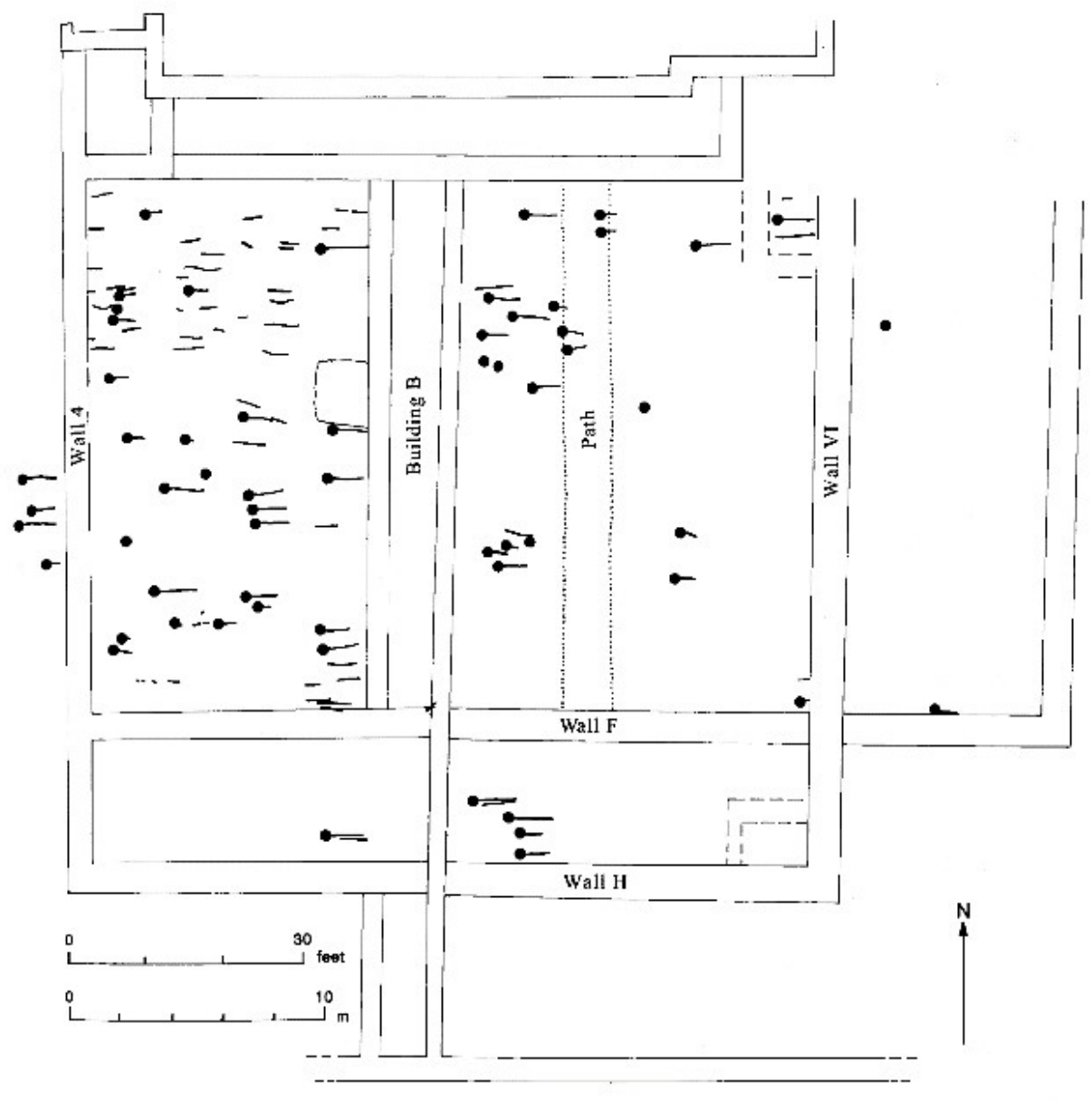

Figure 1b. Cemetery plan showing the early graves at Wearmouth, Durham (reproduced from Cramp 2005, vol 1, fig 8.3).

$77 \times 74 \mathrm{~mm}(220 \times 220$ DPI $)$ 


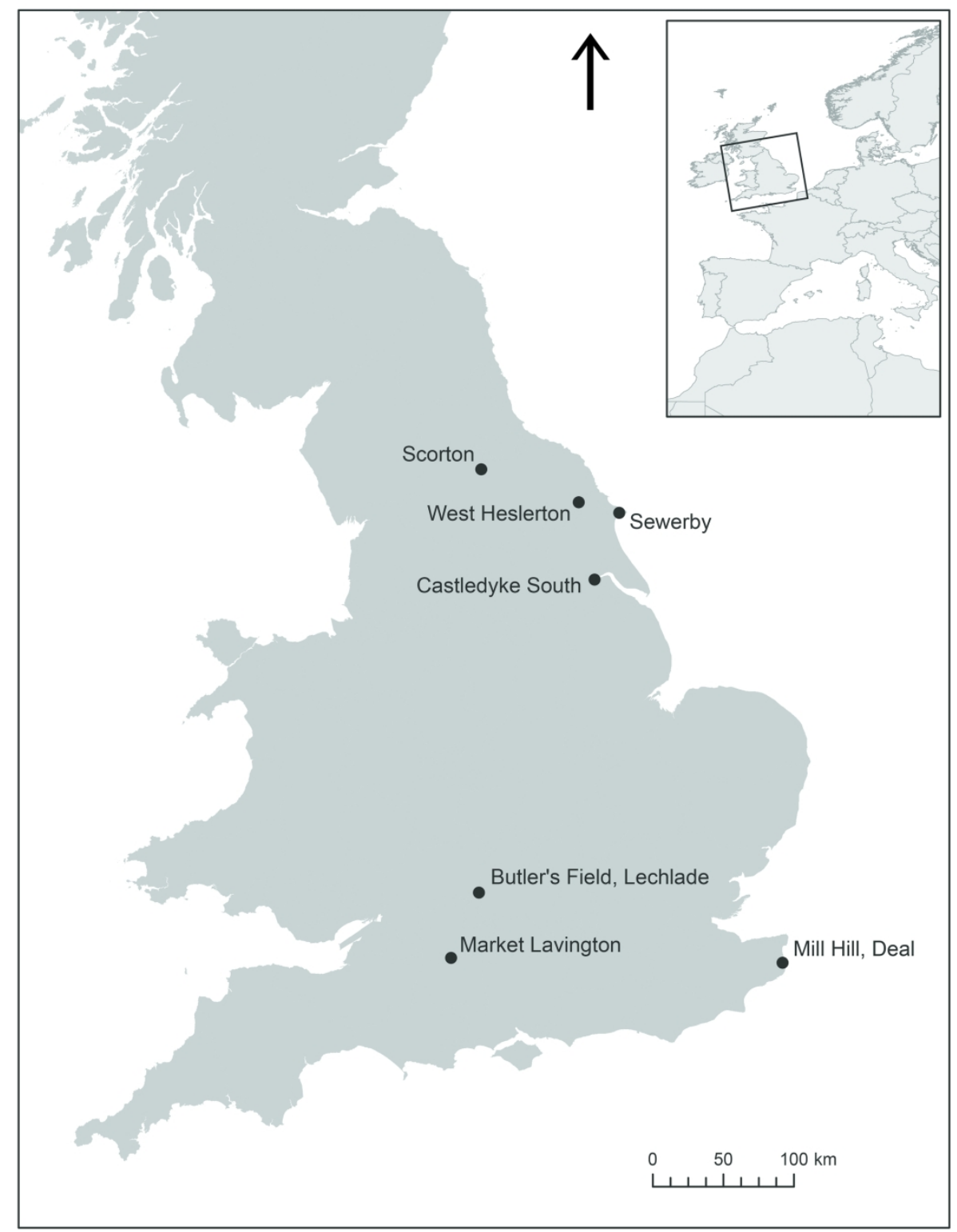

Figure 2 Location of burial sites mentioned in the text $194 \times 250 \mathrm{~mm}(300 \times 300$ DPI $)$ 


\section{Orientations}

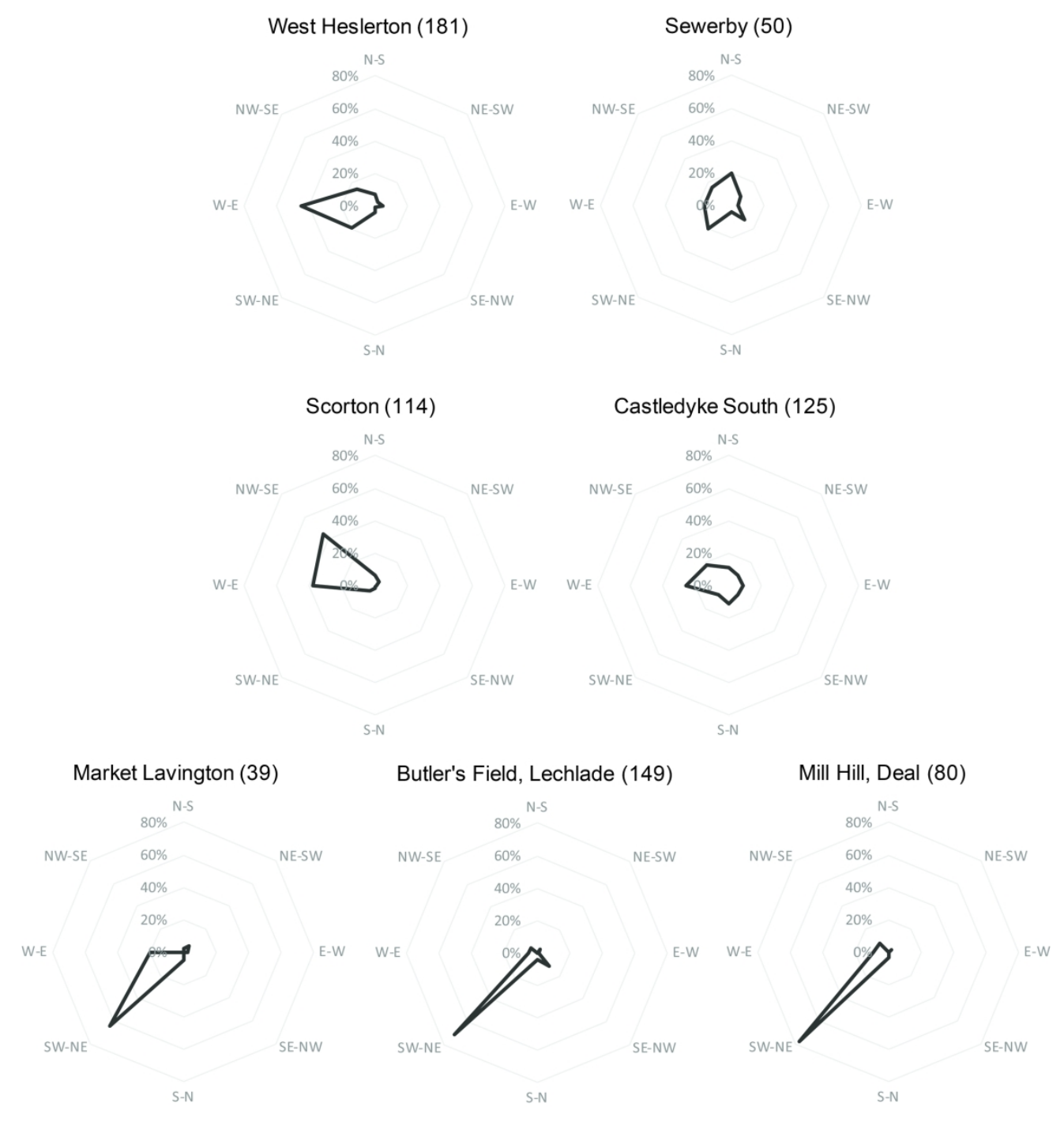

Figure 3 Radar plots of the relative frequency of burial orientations

$204 \times 239 \mathrm{~mm}(300 \times 300$ DPI $)$ 


\section{Grave Shape}

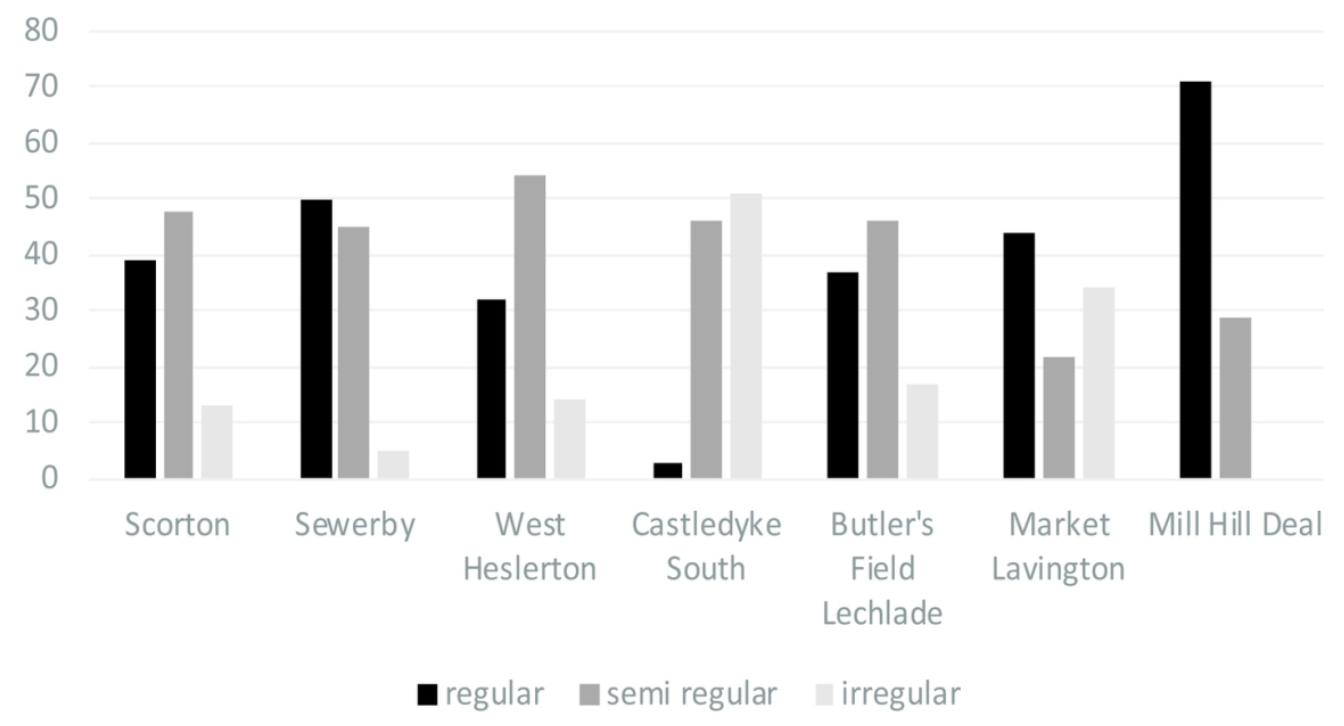

Figure 4 Percentage frequency of grave shapes $118 \times 79 \mathrm{~mm}(300 \times 300 \mathrm{DPI})$ 


\section{Body Position}

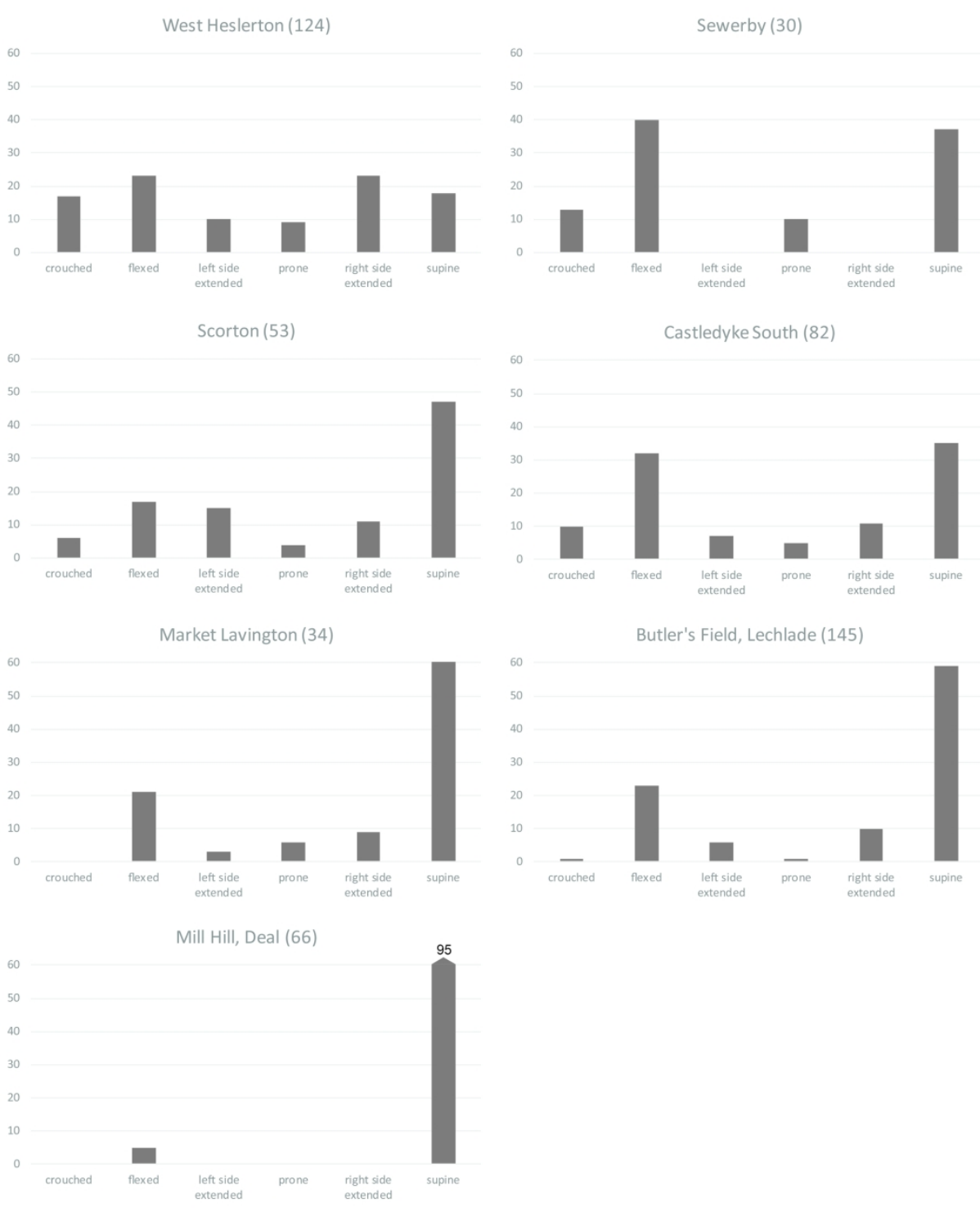

Figure 5 Percentage frequency of body positions

$207 \times 265 \mathrm{~mm}(300 \times 300$ DPI $)$ 

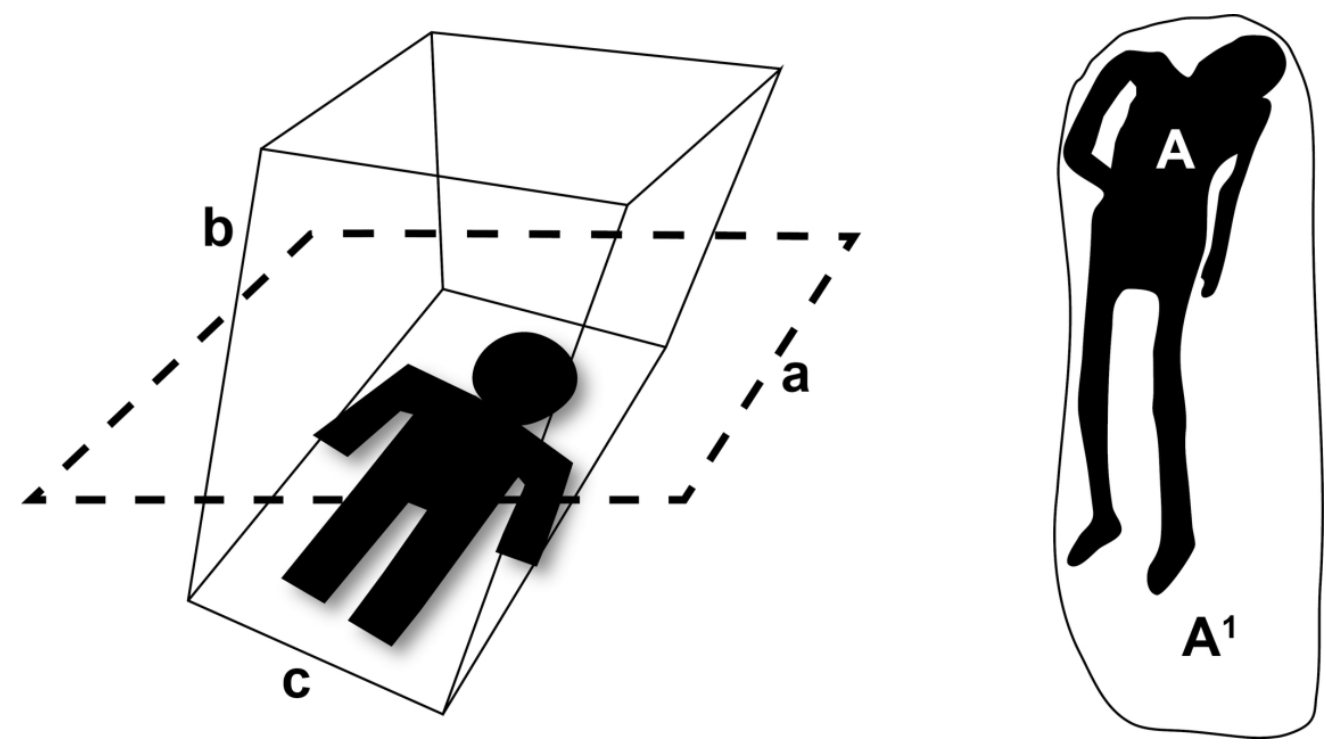

Figure 6 Volumetric analysis of graves is complicated by a number of factors: a) the degree that graves have been truncated after burial, b) whether the grave cut was vertical or sloped, c) the horizontality of the surface and base of the grave cut. To mitigate against the effects of these unknown coefficients, twodimensional area analysis was calculated in this analysis as a proxy for 'volume' by deducting the area of the body ' $A$ ' from that of the grave ' $A 1$ '.

$178 \times 98 \mathrm{~mm}(300 \times 300 \mathrm{DPI})$ 


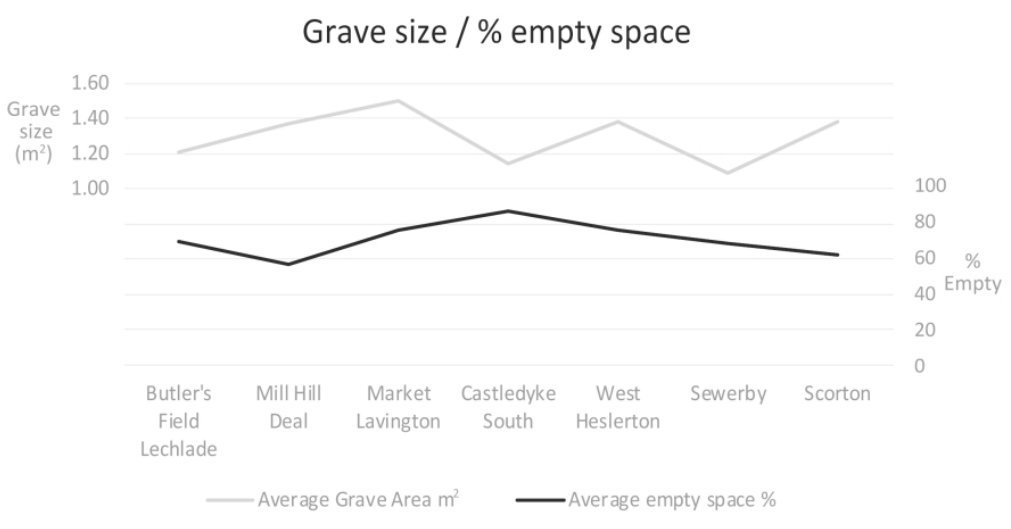

$\%$ empty space by age

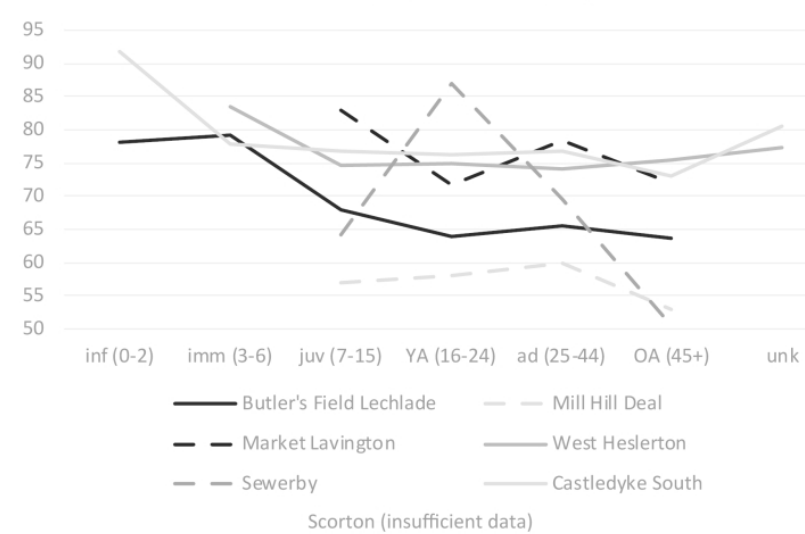

Figure 7a (above) Average grave size and the percentage of empty space; b (below) Percentage of empty space by age band.

$210 \times 297 \mathrm{~mm}(300 \times 300 \mathrm{DPI})$ 


\section{Object Categories}

A

Sewerby (60)

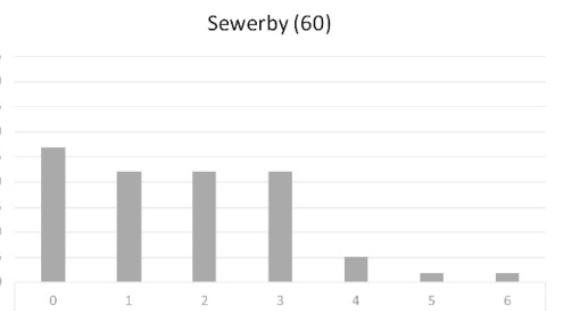

Scorton (123)

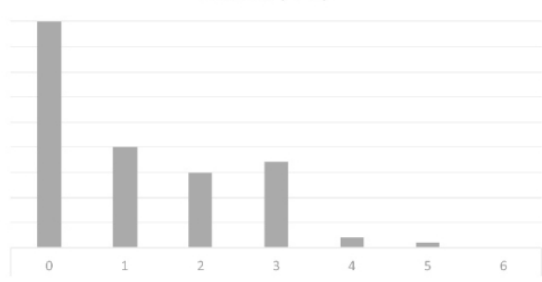

Castledyke South (154)

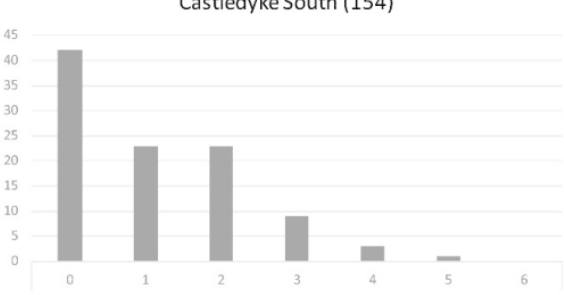

B

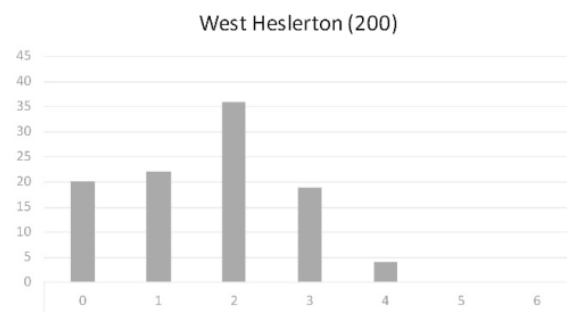

Butler's Field, Lechlade (161)

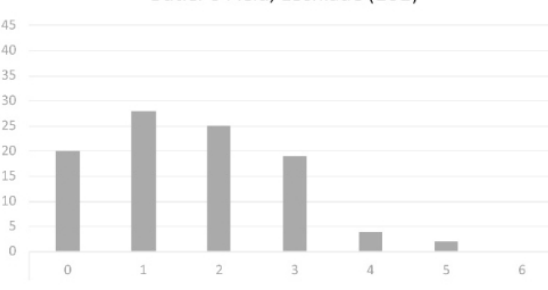

Market Lavington (42)

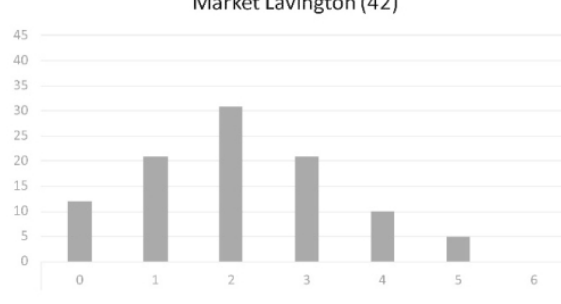

Mill Hill, Deal (81)

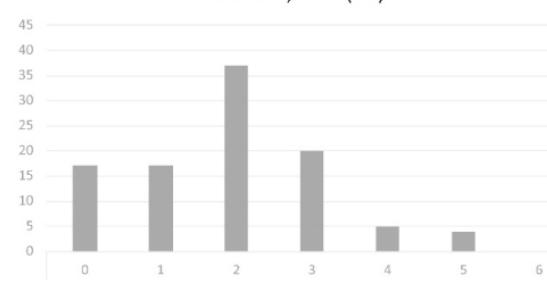

Figure 8 Percentage frequency of object categories

$159 \times 209 \mathrm{~mm}(220 \times 220$ DPI $)$ 